\title{
OVERVIEW OF EMPLOYMENT PROGRAMS AVAILABLE TO NEWCOMERS IN \\ TORONTO AND THEIR ROLE IN BREAKING DOWN BARRIERS TO EMPLOYMENT
}

\author{
by \\ Josina Myrie \\ A Major Research Paper \\ presented to Ryerson University \\ in partial fulfillment of the \\ requirements for the degree of \\ Master of Arts \\ in the Program of \\ Immigration and Settlement Studies
}

Bachelor of Science (BSc.), University of the West Indies, Mona Campus, 2000

Toronto, Ontario, Canada, 2016

(C) Josina Myrie 2016 


\section{AUTHOR'S DECLARATION FOR ELECTRONIC SUBMISSION OF A MRP}

I hereby declare that I am the sole author of this MRP. This is a true copy of the MRP, including any required final revisions.

I authorize Ryerson University to lend this MRP to other institutions or individuals for the purpose of scholarly research.

I further authorize Ryerson University to reproduce this MRP by photocopying or by other means, in total or in part, at the request of other institutions or individuals for the purpose of scholarly research.

I understand that my MRP may be made electronically available to the public. 


\title{
OVERVIEW OF EMPLOYMENT PROGRAMS AVAILABLE TO NEWCOMERS IN TORONTO AND THEIR ROLE IN BREAKING DOWN BARRIERS TO EMPLOYMENT
}

(C) Josina Myrie 2016

Master of Arts

Immigration and Settlement Studies

Ryerson University

\begin{abstract}
This research examines the systemic barriers faced by newly arrived immigrants to Canada in their job acquisition. A thematic content analysis of the government funded Job Search Workshop (JSW) and Employment Ontario Programs from twenty Service Provider Organizations (SPOs) was undertaken to respond to the following questions: How do these programs assist newcomers to overcome the barriers to labour market entry? What do these services offer that address the needs of newly arrived immigrants for access to employment? What are some of the factors that lead to their unsuccess? Social Inclusion theory was applied. Results indicate that the focus of both programs is on pre-employment preparation and making participants more 'employable'. The systemic barriers of the accreditation process and racial/employment discrimination are still major areas that need to be given more attention.
\end{abstract}

Key Words: employment programs, newcomers, labour market access, barriers to entry 


\section{Acknowledgements}

My sincerest gratitude to my supervisor Dr. Rupa Banerjee, for her patience and understanding during some of my most difficult moments while trying to complete this research paper. I am eternally grateful to her for her strong dedication and commitment to this research project and though it was her first time as a supervisor, she assisted me the best way she could with regards to the direction of this paper. A heartfelt thank you to Dr. John Shields, who agreed to be my second reader without hesitation while patiently waiting to review this document. My appreciation for his advice and providing his expertise on immigrant settlement and employment issues.

Many thanks to Igor Rosic, our program coordinator for his support and assistance with any issues pertaining to my research.

Lastly but not least, a huge thank you to my friends Annmarie and Sandra from the ISS program for their support and encouragement during my time at the university. 


\section{Table of Contents}

Author's Declaration.................................................................. ii

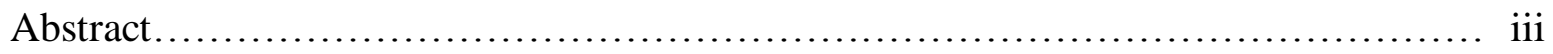

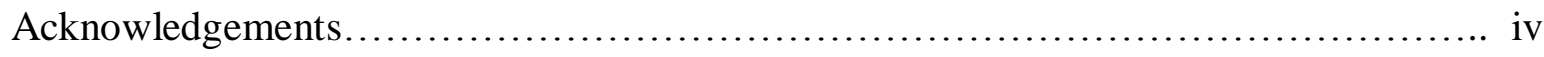

Table of Contents....................................................................... v

Introduction and Background ................................................ 1

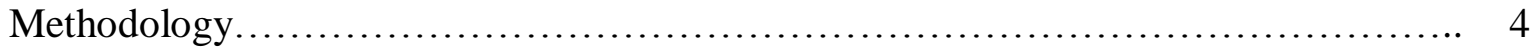

Chapter 1: Literature Review and Theoretical Framework.......................... 7

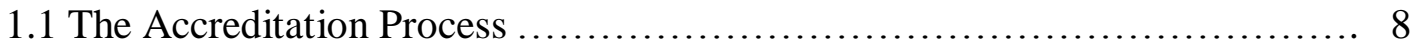

1.2 Devaluation of Foreign Work Experience and Education..................... 10

1.3 Employment Discrimination........................................... 12

1.4 Language as a Barrier.................................................. 15

1.5 Employer's Hiring Practices.......................................... 18

1.6 Theoretical Framework: Social Exclusion and Inclusion................... 20

Chapter 2:Employment Programs and Services Available to Newcomers to Canada... 22

2.1 Job Search Workshops and Employment Counseling..................... 25

2.2 Employment Ontario Program..............................................26

2.3 Bridging Programs...................................................... 28

2.4 Mentoring \& Additional Employment Support Services ...................... 29

Chapter 3:Analysis and Findings............................................... 31

3.1 The Accreditation Process Continued...................................... 33

3.2 Effective Social Capital................................................ 34

3.3 Funding Issues...................................................... 35

3.4 The Changing role of NGOs........................................ 36

3.5 Connecting the Dots................................................ 39

Conclusion, Discussion and Recommendation................................... 41 
Appendix A: Categories/Sub Categories Used in the Data Collection Process.......... 50

Appendix B: Content Table............................................ 51

Appendix C: Description of Employment Workshops offered by Service Provider ........56 Organizations

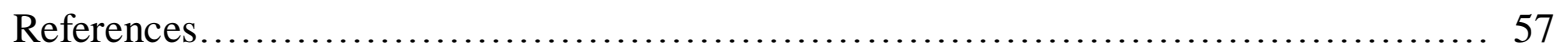




\section{Introduction and Background}

In order to maintain the size of the population of Canada, there should be 2.1 children per woman. Currently the fertility rate is 1.54 (Banerjee and Robson, 2009). Immigration is therefore vital to the demography of Canada and is generally viewed in a positive light by many Canadians (ibid.). Remarking on the necessity of immigration, Citizenship and Immigration Canada (CIC) in its 2007 Annual Report (as cited in Banerjee and Robson, 2009) states that "In a few short years... Canadians who leave school for the workplace will only offset the number of retirements. Immigrants will therefore be a key source of workforce growth in the future" (CIC 2007, p. 6). Despite the importance of the immigration system to offset the ageing population and as a vital supply of labour, recent immigrants to Canada have not fared as well as previous cohorts and over the past two decades their declining labour market outcomes has been the subject of much research (Aydemir and Skuterud, 2005; Reitz, 2001; Frenette and Morissette, 2005; Picot, 2004).

According to Schellenberg and Hou (2005), "success in the labour market is a key ingredient for financial well-being" (p. 49) and "earnings represent the major source of income for most families" (p. 50). The decline in the economic circumstances of recent immigrants to Canada has thus been reflected in their higher rates of unemployment, lower earnings and lower labour force participation, (Grant and Sweetman 2004). As cited by Shields, Kelly, Park, Prier and Fang (2011a), since the late 1970s the relative income levels of immigrants have decreased by $25 \%$ while those of the Canadian born improved by $12 \%$. Although immigrants who arrived prior to the 1980s experienced an initial earnings gap compared to the Canadian-born however, as cited by Picot (2004), this eventually narrowed as they adjusted to labour market conditions in the host society.

Schellenberg and Hou (2005) assert that this initial earnings gap increased steadily throughout the 1980s and 1990s. The wages of immigrants who arrived to Canada in the 1970s and 1980s eventually caught up with those of the Canadian born however, but only after 16 to 20 years, with the former earning $85 \%$ of the latter (Picot 2004). As cited by Shields (2004), the earnings gap of newer cohorts of immigrants has dissipated even further from the 1990s, which raises questions as to whether the income of newcomers will ever be on par with their local born counterparts (Frenette and Morissette, 2005). 
With regards to immigrants' access to the labour market, before the $1980 \mathrm{~s}$, newcomers to Canada had a higher level of participation and were equally able to obtain full-time, full-year employment as their local-born counterparts (Schellenberg and Hou 2005). This subsequently diminished (Reitz 2001b) and continued throughout the 1990s with a large gap emerging between immigrant and Canadian-born women (Schellenberg and Hou 2005). Research on the quality of employment that immigrants obtain indicates that rates of involuntary part-time work, temporary job acquisition and over-qualification were higher for these groups of individuals than the local born population. In 2008 for example, $38 \%$ of immigrants were employed involuntarily on a part-time basis as opposed to $30 \%$ of non-immigrants. Sixteen percent of immigrants who landed within the previous five years worked in temporary positions which was nearly double that of their Canadian-born counterparts (Statistics Canada, 2009).

The decline in labour market outcomes of immigrants has caused a resulting increase in their poverty levels, which also correlates with their time of entry. Immigrants who arrived before 1992 were reported to have low-income cut-off (LICO) scores similar to their Canadian- born counterparts at $14.2 \%$ and $13.8 \%$ respectively. Between 1992 and 2001 this figure rose to the mid to high 20s and the poverty level for those who arrived between 2002 and 2006 more than tripled that of the local born at 45\% (Shields et al. 2011a). Fleury (2007) observes that newly arrived immigrants are among the five groups of individuals to experience persistent poverty in Canada. In addition, approximately $65 \%$ of newcomers are relegated to a state of poverty during their first ten years in Canada of which two-thirds are subjected to, during their first year (Picot, Hou and Coulombe, 2008).

The declining labour market outcomes over the past two decades has been attributable to and not withstanding among other things, the change in language abilities and region of birth of more recent cohorts, discounting of their foreign labour market experience and schooling and more general macro economical conditions at the time (Ferrer and Riddell, 2008; Aydemir and Skuterud, 2005; Green and Worswick, 2002, Picot, 2004). Other factors include an overall decline in employment opportunities for all new entrants to the job market and a rise in the educational levels of the Canadian-born, which increases the competition for newcomers (Reitz 2007). 
These diminishing returns have caused many to question the rationale and success of the immigration program, as one of its main objectives is the contribution to the economic development of Canada and on average over 200,000 immigrants are granted permanent residency status on a yearly basis (Citizenship and Immigration Canada -Facts and Figures, 2012b). Their skills are constantly discounted and underutilized (Reitz, 2001a) and despite numerous post migration programs, immigrants still encounter many barriers to entry into the labour market.

This study will do an analysis of employment programs available to newcomers to Canada at the federal and provincial levels, designed to equip them with better labour market access. A content analysis of the Job Search Workshop (JSW) and Employment Ontario Programs will be undertaken that seek to answer the following questions: How do these programs assist newcomers to overcome the barriers to labour market entry? What do these services offer that address the needs of newly arrived immigrants for access to employment? What are some of the factors that lead to their unsuccess?

This research responds to these questions in the following way: An overview of the literature will first be provided, outlining the major barriers to access to employment for newcomers. The four major barriers that I will be focussing on in my analysis are: the accreditation process, employment-based discrimination, the personal conditions of newcomers and employer's hiring strategies. I will then provide a description of the general labour market access programs and services for newly arrived immigrants to Canada. The third section presents the findings of my research and an in depth analysis of the JSW and Employment Ontario Programs and the significance of these findings. I'll conclude with a general discussion and recommendations. In my general analysis, I will also look at the gaps in program offerings and examine other services that have been implemented to address the needs of newcomers for sustainable employment. 


\section{Methodology}

In examining the barriers to access to employment faced by newcomers to Canada and the programs designed to address these obstacles, it is important to understand the concept both from the perspective of the immigrant community as well as from a macro level. In this regard, this paper is situated in the paradigm of constructivism. As the review of the literature indicated that obtaining adequate employment was one of the greatest challenges for newly arrived immigrants to Canada (Statistics Canada, 2007; OCASI, 2012), it was important to first gain an understanding of the labour market needs of this population in order to ascertain how the programs analyzed, meet these needs.

The experiences of former participants of the Job Search Workshops (JSW) and Employment Ontario programs gained from a review of the literature were also highlighted, to further explore their anomalies as well as the aspects of the programs that address the principal barriers to labour market access for newcomers. In conjunction, the needs of the business community as well as immigration policies were also examined, in order to bring to the fore possible mismatch factors not being currently addressed by these employment programs, with the aim of forming a basis for further analysis and recommendations. My own experience was also taken into account to obtain a more in depth description of the labour market services analyzed, as well as to highlight issues not explored in the literature. A holistic approach to knowledge construction was employed based on narratives of former participants, the settlement sector and employers.

In this research I sought to address the following questions: How do the Job Search workshops and Employment Ontario programs assist newcomers to overcome the barriers to labour market entry? In conjunction with this question I examined the aspects of these programs that address particular barriers according to the literature. Other subsidiary questions which guided my research are: What do these services offer to meet the needs of newly arrived immigrants for access to employment? What are some of the factors that lead to their unsuccess?

This study not only seeks to understand in greater detail how the employment programs and services help newly arrived immigrants to overcome the barriers faced to labour market access, but also factors that are not being addressed by these programs to meet the job related needs of the newcomer community. Findings of the research were also compared with pre-existing 
theories in order to make inferences as well as recommendations on other programs and services that could be employed to address grey areas. Personal experiences were also included, in order to shed further insight on aspects of the programs not covered in the literature.

I undertook a thematic content analysis of the Job Search Workshop (JSW) and Employment Ontario Programs, which are funded by the Government of Canada. Twenty Service Provider Organizations (SPOs) were selected using a convenience sample of the most physically accessible subjects. These organizations were first researched on the JSW (www.jswontario.org) and Ministry of Training Colleges (www.tcu.gov.on.ca/eng/employmentontario) websites respectively. The Immigrant Serving Organizations (ISAs) chosen were diverse in scope and nature and included non-profit and community based corporations, multicultural, multi-service agencies, ethno-specific agencies, employment organizations, non-governmental organizations of a charitable nature and post-secondary institutions. Multi-service ISAs provide a range of services to newcomers from a diverse cultural and linguistic background predominantly at one location, whilst ethno-specific agencies are community based and usually cater to a particular ethnic group (Sadiq, 2004).

The most geographically accessible SPOs in the Toronto region were visited, to obtain print material such as pamphlets and brochures collected from the resource and reception areas, which were open to the public and visibly displayed. I selected a diverse sample representative of newcomer settlement from the Scarborough, North York, Etobicoke and downtown core areas. Other content that was analyzed included the most recent annual reports and general information garnered from the organization's websites deemed to be trustworthy.

Content analysis was selected due to the large amount of textual information analyzed, in order to ascertain the aspects of the JSW and Employment Ontario programs that address barriers to access to employment for the newcomer community. A combined form of analysis was chosen to provide a numerical overview as well as an in depth explanation of findings. Categories and themes that emerged from the literature were used according to the concepts outlined and the existing written information was perused in order to ascertain frequencies. The data was collected using a content table, which included the principal barriers to access to employment. My research did not include the use of human subjects and therefore no one was implicated in the process or their confidentiality undermined. As previously referenced, data was gathered 
from pre-existing material made available to the public on display. Agencies analyzed were not identified and their findings remain anonymous. Information garnered was organized under four main headings: the Accreditation Process, Racism/Discrimination, Employee's Personal Conditions and Employer's Hiring Strategies. These categories were subsequently divided into sub categories and themes from the published material which were identified and categorized accordingly (See Appendix A).

The content table was instrumental in order to establish patterns and make linkages between the programs, in the data analysis process. Themes under each category were tallied and findings presented in the form of a numerical overview, as well as a critical analysis, according to a review of the literature. Factors not currently being addressed by the Job Search Workshop and Employment Ontario Programs in relation to the labour market needs of newcomers were also explored. Pursuant to this, other job related services were examined, in order to make recommendations for further considerations and policy implications. Although the method of data collection used was the most ideal according to the goals of my research, the process was very time consuming. In order to undertake an in-depth analysis of the subject matter, various sources had to be consulted and a wide array of information garnered which were also subject to budgetary constraints. 


\section{Chapter 1}

\section{Review of the Literature \& Theoretical Framework}

In investigating the challenges experienced by newly arrived immigrants to Canada in the settlement process, Statistics Canada, (2007) using the Longitudinal Survey of Immigrants, reveal that finding employment was the greatest challenge for respondents. Across all immigration categories, finding an adequate job was the greatest difficulty cited by $46 \%$ of new immigrants, followed by learning a new language and adapting to the weather. The primary difficulties outlined by respondents when seeking employment include: "lack of work experience, language problems, lack of foreign credential recognition and lack of job contacts or networks" (p. 8).

Findings from the study commissioned by OCASI (2012), concur with those of Statistics Canada (2007) with $61.8 \%$ of the respondents identifying that finding employment was their most important challenge, followed by limited English language skills and social isolation (pp. 7, 34). The fact that obtaining employment was identified in both studies as one of the greatest obstacles for newcomers in the settlement process, highlights the importance given to this need. For the purposes of this research, a newcomer is someone who has been in Canada for four years or less given the recent changes to the Citizenship Act (Black, 2014). Newcomers will be used interchangeably with 'newly arrived immigrants' throughout this study.

Occupational barriers can be defined as "entry requirements that seek to control access to employment in different occupations" (Ahamad, Roberts, Sobkow and Boothby, 2003 p. 8) and can be described as formal or informal. Formal (or institutional) barriers are the regulatory requirements that are instilled to govern entry to occupations, such as certification, licensing or membership in an association. Informal barriers on the other hand are usually unspecified and undocumented and cannot be easily identifiable, but nevertheless encompass employment restrictions. An example of this would be the unwillingness on the part of employers to recognize foreign credentials or grant the work experience needed for newly arrived immigrants to become certified (ibid). 
When immigrants are unable to enter their professions because of the formal and informal barriers posed, they enter into a process of 'deskilling' and underutilization of their skills (Bauder, 2003; Reitz, 2001a). This leads to an underrepresentation of immigrants in the upper segment of the labour market. Bauder (2003) refutes the idea that the discounting of immigrant labour is a natural occurrence in the transitionary period or as a result of migration to big cities. $\mathrm{Li}$ and Teixeina (2007), point to the challenge faced by world cities of incorporating immigrants into the economic and social spheres who as a result of labour market segmentation often find themselves at the lower end of the income category. Rather than primarily the occurrence of market forces, Bauder (2003) in contrast, posits that regulatory institutions actively engage in the exclusion of immigrants from the more skilled positions in the labour market.

\section{The Accreditation Process}

It is argued therefore that professional associations and the state work in tandem to reserve the most desirable occupations for the native born population and those who were educated in Canada, thereby excluding immigrants from these positions (ibid.). As cited by Bauder (2003), despite the high level of educational attainment of immigrants to Canada since the 1950s, there exists a huge discrepancy between their qualifications and their employment outcomes. Reitz and Thompson's study illustrates that education does not prove to be an accurate indicator of stellar labour market performance for newcomers, who often receive lower returns on their credentials than Canadian born workers.

The professional organizations, which are supported by federal and provincial legislation and reinforced by the rigorous certification system, thus assist in the promotion of their own members by imposing differentiated measures on foreign as opposed to Canadian-educated workers. The preference given for individuals with Canadian education, training and experience is more evident in the stipulations required for licensing in the regulated professions. Studies across the provinces reveal that less than half of the immigrant population in regulated occupations are successful in obtaining Canadian accreditation and in the medical field, only 5\% of foreign-educated doctors receive licensing (Bauder, 2003). Basran and Zong (1998), affirms that this is further compounded by the unavailability of sufficient internship positions in order to fulfil the requirements of the accreditation process. 
Bauder (2003) suggests that the licensing procedures are more in favour of applicants who were educated in Canada. This is also evident in the difference of costs in order to obtain professional credentials. In the field of Architecture for example, graduates from Canadian schools are charged a modest fee of $\$ 300$ for the assessment of their educational qualifications by the Canadian Architectural Certification Board (CACB), whilst foreign applicants are charged $\$ 1,000$ (CACB, $2003 \mathrm{a}, \mathrm{b}$ ). These associations (supported by regulations from the state and corporate management) function as 'gatekeepers of professionalism' as they set entry requirements which are not in the favour of newly arriving immigrants and are 'culturally biased' and exclusionary.

Individuals who are mostly affected by the deskilling process are usually newly arriving immigrants who enter under the 'Skilled-Worker' category. These highly skilled immigrants often resolve to accept work, which is not in alignment with their qualifications (ibid.). In some cases they accept precarious employment or 'survival jobs', which are often difficult for them to break away from and move forward, thereby perpetuating the cycle of underemployment (OCASI, 2012). While some immigrants decide to undertake the accreditation process, which oftentimes is prolonged and costly, draining their resources in the process, others simply switch careers (Bauder, 2003) abandoning their goals, dreams and aspirations and culminating in a process known as 'brain waste'.

The effect of this deskilling process is also evident in the credential assessment of foreign educated engineers in Canada. Those who do not fulfil the accreditation requirements are certified at a lower standard and are called 'technicians' or 'technologists', thus having to work for a lower salary. In some countries for example, individuals are not required to go through the licensing process in order to enter a regulated profession and in other cases are only mandated to do so for some aspects of the field (Bambrah, 2005). Reitz (2014) posits that the earnings deficit from skill underutilization of immigrants has increased from about 4.80 billion in 1996 to over $\$ 11.37$ billion in 2006. As cited by the Office of the Fairness Commissioner, the Royal Bank of Canada estimated this amount to be $\$ 30.7 \mathrm{~b}$ in 2006 . The underutilization of immigrants' skills leads to wasted resources and human potential and can also reduce their fiscal contribution through taxation. The underemployment and unemployment of immigrants also further impacts the 'sustenance of pensions and social security programs' (Deters, 2011, p. 5). 


\section{Devaluing of Foreign Work Experience and Education}

A study carried out by Statistics Canada in 2005 reveals that lack of experience in the Canadian workplace was the primary difficulty faced by immigrants when trying to obtain employment, even after two years of being in the country. Reitz (2001b) in his research indicates that the value of foreign experience in the labour market equates to zero. In this case immigrants are treated as new entrants to the workforce regardless of the credentials that they possess and are usually compared to Canadians who have just completed their schooling. The problem becomes more pronounced for older immigrants considered as 'lower level entrants' to their professions thereby placing them at an economic disadvantage (Picot and Sweetman, 2005).

Bauder (2003) posits that the notion of 'Canadian experience' is often used to exclude newly arriving immigrants from the upper segments of the Canadian labour market. In contrast, occupations that are of a more low-skilled nature and not highly esteemed by Canadian-born residents do not require Canadian experience. In the security guard sector for example, the lack of Canadian experience is not an impediment for employment. Both regulated and unregulated professions demand Canadian experience and in the case of the latter, serve as an informal exclusionary measure for immigrant workers. Whilst employers may be unfamiliar with the qualifications of newly arriving immigrants and therefore ill-equipped to adequately evaluate their foreign credentials, it is clear that Canadian experience can also be used as a barrier to access to employment for newly arriving immigrants. In addition, it can also be a measure to distinguish between Canadian-born workers and immigrants. The foreign experience of newcomers thus becomes devalued when their credentials are not recognized (ibid).

Oreopoulos and Dechief (2011) illustrate that when deciding to interview individuals with foreign backgrounds, Canadian experience plays a greater role than education acquired locally or overseas. The authors remarked that callback rates increased from 5\% to $8 \%$ for internationally educated professionals who listed the possession of Canadian experience with only one company. Results of the study also seem to indicate that the greater the years of local experience in the chosen profession, the higher the chances of a callback. With particular reference to my research, the employment programs analyzed provide job placement opportunities to participants and also offer financial incentives to employers to offset some of the costs associated with onthe-job training and work experience (Ministry of Training Colleges). 
Some regulated occupations also require that immigrants possess Canadian experience before entering the field. The Professional Engineer's Act 1990 for example (as cited in Gurmeet, 2005), requires that an applicant possesses a year's worth of experience in a Canadian jurisdiction under the supervision of legally authorized personnel in the field. The medical profession also requires that doctors undergo an internship as part of the accreditation process, which is often difficult to obtain (Bauder, 2003).

Despite the various policy initiatives enacted by the government to combat the deskilling of immigrants such as credential assessment, fair licensing standards and bridging programs, immigrants' qualifications are still not being widely accepted (Reitz et al. 2014). Bill et al. (2003) points to some of the inconsistencies that exist in these procedures across the provinces and hence contribute to the barriers to access to employment for newly arrived immigrants. While some licensing procedures are specified at the federal level and are applicable to all provinces and territories (for example licensing for Air Traffic Controllers), others are specified at the provincial or territorial level and different regulations apply in each jurisdiction. In addition, some occupations are only licensed in specific provinces.

Gurmeet (2005) states that the federal government delegated its licensing authority to the provincial government who subsequently entrusted it to membership-based, self-regulating professional associations (p.52). The provincial bodies were now at liberty to make amendments to their licensing criteria which would have further implications for immigrants. An example of this is cited above with regards to possessing one year of 'Canadian experience' as a requirement for accreditation which also does not have a predetermined definition. Newly arrived immigrants who do not possess the needed Canadian experience oftentimes opt for entry level positions or 'survival jobs'. In some cases they work as volunteers for long periods without a salary (Bauder, 2003).

Reitz (2001a) speculates whether the discounting of foreign education by employers is due to the actual relevance of these credentials to the Canadian workplace or because employers are ignorant of the true labour market value of these qualifications. As cited by some employers, what is of most importance to them is understanding how the skills of immigrants can be transferred into earnings potential and how the previous courses done within their field of study facilitates this. Hence, the problem not only rests with the assessment of their credentials but 
with the comprehensiveness of the assessment done by the respective organization (Owen, 2007).

In light of this, the underutilization of immigrants' skills and experience may not be an intentional act on the part of employers, but rather because they may be ill equipped to evaluate these credentials as a result of the costs involved (Alboim et al. 2005) or unknowledgeable about the process (Reitz, 2001a). The discounting of foreign qualifications then, may be an effort to diminish the risk associated with the lack of familiarity with these qualifications, in the face of increased competition from Canadian applicants (ibid.).

\section{Employment Discrimination}

In addition to the desire of employers to avoid making mistakes stemming from the unfamiliarity of foreign credentials and the consequences that may ensue, Reitz (2001a) posits that the discounting of foreign qualifications may also be attributable to 'cultural or racial' biases that exist within the Canadian society. There may be a perceived tendency to believe that the quality of foreign education may be inferior to that of Canadian education which may influence the hiring practices of employers. This is further reiterated by findings that illustrate that immigrants who completed their education in Canada receive higher earnings returns than those who acquired their education solely abroad (Reitz and Sklar, 1997; Pendakur and Pendakur, 1998). Alboim et al. (2005) further state that a Canadian degree serves to increase the value of a foreign obtained degree by immigrants thereby elevating their wage levels and returns to their total years of schooling. This inherently shows a preference for Canadian credentials and a lesser consideration for the human capital of the immigrant community.

Immigrant skill underutilization is considered as a form of employment discrimination. This is defined as "negative employment decisions based on statuses such as birthplace or origins rather than solely on credentials and qualifications directly related to the potential productivity of the employee" (Reitz 2001a, p. 353). This is often difficult to measure and may be supported by rationale pertaining to education quality or ignorance on the part of employers. In his study, Reitz (2001a) examines the effects of skills underutilization on the earnings of immigrants. It was discovered that differences exist in the earnings of immigrants across origin groups regardless of their education and work experience. These groups include immigrant men from 
non-European backgrounds, Blacks from Africa and the Caribbean, Filipinos, Chinese, South Asians and other Asians earn anywhere between 15 and 25\% lower than immigrants of European origin (p. 367).

In addition to prejudice and discrimination against immigrants based on foreign origins, this can also be evident in racial or ethnic background, which also impacts their earnings and their access to employment based on their human capital. Pertaining to the overall economic situation of racial minorities, visible minorities tend to have "much lower relative household incomes and higher poverty rates than do ethnic groups of European origin" (Kazemipur and Halli 2001, 2000, 107-109). Data from the ethnic diversity survey (EDS) (2002) indicate that "for visible minorities, the incomes are $\$ 7,686$ less than the local average, while for Whites, they are $\$ 1,895$ above the local average thus the gap is $\$ 9,581$ " (p. 4). The data obtained from the EDS was used to portray the mean individual-equivalent household incomes for ethnic groups, relative to the mean for the census metropolitan area of residence (Reitz and Banerjee, 2007 p. 4).

The 2002 ethnic diversity survey indicates that $35.9 \%$ of visible minorities reported experiencing discrimination based on ethnicity, race, skin colour, language, accent or religion, compared with $10.6 \%$ of Whites. The highest rate of discrimination pertained to Blacks at $49.6 \%$. With respect to the experience of recent immigrants, $33.6 \%$ of racial minorities "report having experienced discrimination, compared with $19.2 \%$ of those of European origin" (Reitz and Banerjee, 2007, p. 9).

Block and Galabuzi (2011), utilizing statistics from the 2006 long form census data, found that there is still a colour code at play in the Canadian labour market. This leads to racialized immigrants occupying low wage jobs that are of an insecure nature. Even in periods of economic boom for example from 2000 - 2005, there was still a pay gap between racialized and nonracialized Canadians. Results indicate that during this economic period, racialized Canadians earned 81.4 cents less than what non-racialized Canadians obtained. In addition, it has been found that racialized Canadians have higher levels of unemployment and lower income levels than do non-racialized Canadians. Jobs obtained by the former group are usually temporary and include an overrepresentation in low paid positions such as call centres, security services and janitorial services (Block and Galabuzi, 2011). 


\section{Name-Based Discrimination}

Oreopoulos (2009) examines the existence of name-based discrimination when selecting candidates for the job interview process. The author points to the importance of the resume in establishing an initial point of contact with employers. Findings reveal that resumes from Canadian born individuals with English sounding names are more likely to be selected for a job interview than those with ethnic names. The study found that "16\% of resumes with Englishsounding names, Canadian education and experience received a call back from an employer, compared to only $5 \%$ of resumes with foreign-sounding names" (p. 25). It is interesting to note that no differences in call back rates were noted between Canadian and British resumes, possibly because of similar levels of language fluency and cultural practices (Oreopoulos, 2009).

In another study done by Oreopoulos and Dechief (2011), it was also found that resumes with English-sounding names were 35\% more likely to receive callbacks than resumes with ethnic sounding names. Oreopoulos (2009) speculates that a possible explanation for this difference in call back rates could be as a result of discrimination on the part of employers who use an individual's name and employment experience as indicators of their language and cultural skills.

Stanley et al.'s study, posits that name based discrimination on the part of employers is more likely unintentional due to the conditions under which employers sort through resumes to arrive at a decision. Further to this, Oreopoulos and Dechief (2011), state that pursuant to 'classical economic theory', employers will prefer to hire individuals that will make their companies more lucrative. Driven by productivity concerns then and faced with inadequate tools to attest to the skill sets of immigrants as well as limited time and budget, employers may inadvertently use queues such as 'names' or 'country of education/experience' to decipher if the individual possesses the desired language skills (ibid.).

Crandall and Eshleman (2003), state that an employer's implicit biases may eventually come to the fore when rejecting an applicant due to language skills concerns, as their name and country of origin may offset certain stereotypes. Oreopoulos and Dechief (2011), explore this in further detail and examine whether name based discrimination can be attributed solely to productivity concerns or issues of prejudice and whether or not this was being done consciously by employers. 
Responses from employers and recruiters interviewed, indicate that faced with overwhelming pressure to avoid bad hires and due to time constraints to choose resumes, some recruiters often develop their own personal strategies in the selection process. An individual with an international name may also not be selected for an interview based on past negative immigrant experiences and the uncertainty involved with hiring internationally trained individuals. On the other hand recruiters may prefer to hire individuals with English sounding names based on the 'comfort factor' and the issue of 'social compatibility' with coworkers. These individuals are perceived as possessing a greater understanding of the Canadian workplace culture and communication skills, thereby minimizing risk aversion (Oreopoulos and Dechief 2011 pp. 36 - 40).

Higher call back rates for resumes with English sounding names, indicate that name-based discrimination does play a role in this difference. Employers often use 'name and country of education or experience' as indicators of an individual's language skills and their suitability for the job. All things being equal, when factors such as language fluency in both English and French, accreditation of credentials, legal working status and Canadian contacts for references were listed on resumes, a reduction in the degree of discrimination was not noted for non English-sounding names. As cited by Oreopoulos and Dechief (2011), this gives further credence to the fact that while recruiters may inherently try to avoid discrimination, their decisions may still be influenced by subconscious beliefs and attitudes based on pre-existing stereotypes, which cause them to overweight these concerns (ibid.).

\section{Language as a Barrier}

Since language has a direct effect on one's productivity within the labour market and positively influences employment returns, it is considered as a major human capital attribute as it is embodied within the person (Chiswick and Miller, 2001; Adamiti-Trache, 2013). Alboim et al. (2005) state that human capital assessment can be divided into three main areas: academic credentials, occupational competencies and language skills. Language is a contributing factor to the native-born immigrant earnings gap and the discounting of immigrants' human-capital investments. The less proficient English and French language skills of immigrants in Canada can prevent them from fully utilizing and thus receiving the complete benefits of their educational qualifications (ibid.). 
A shift in the source countries of immigrants and weak language skills of individuals with a foreign mother tongue has been one of the contributory factors to the declining labour market outcomes of immigrants over the past two decades (Picot and Sweetman, 2012; Aydemir and Skuterud, 2005). The increase in the percentage of immigrants over the years from nontraditional source countries gives further credence to this point. Picot (2004) state that between 1981 and 2001 the proportion of immigrants that came to Canada from the United States, Northern Europe, the Caribbean, South and Central America and Southeast Asia fell from 65 to $28 \%$. In contrast, the proportion from such regions as Eastern Europe, South Asia (India and Pakistan) East Asia (China, Korea and Japan) Western Asia (Iraq, Iran and Afghanistan) and Africa increased from 35\% in 1981 to $72 \%$ in 2001 (pp. 36-37). The authors maintain that the human capital of these immigrants may be less in sync with the Canadian system due to language, culture and education quality.

From a business perspective, language was the number one difficulty cited by small and medium-sized enterprises in integrating immigrants into the workplace (Bourgeois et al. 2006). With regards to language acquisition specifically for the labour market, employers are interested in the worker's ability to use occupation specific terminology and to communicate effectively in the workplace. For the regulated professions, the accreditation body needs to have the assurance that individuals have the language skills to effectively work in their fields (Alboim et al. 2005).

Deters (2011) asserts that language is paramount to the integration of newcomers in the receiving society and "essential for social cohesion, which provides a sense of security and common purpose and contributes to economic success" (p. 2). Thus, a lack of proficiency in the official language of a country can also lead to unemployment and underemployment. The deskilling of immigrants over the past two decades due to language ability can also be attributed to the fact that possessing a high degree of proficiency was not a compulsory deciding factor in the selection of 'skilled workers' to Canada. This was changed in 2010 when the federal government made it mandatory for applicants under the Federal Skilled worker program to possess a level 7 of the Canadian Language Benchmark which equates to an intermediate level of English. The current selection criteria for language equates to 28 points for either English or French whereas previously education accounted for maximum points (Citizenship and Immigration Canada- Federal Skilled Workers, 2012b). 
Alboim et al. (2005) point to the inadequacies of the language testing system for the selection of immigrants to Canada. They comment that while immigrants require knowledge of at least one of Canada's official languages, their ability to practise their occupation in either English or French is not measured. The tests that are administered are also generic in nature and individuals do not have to demonstrate occupation-specific terminology. This lies in stark contrast to the desires of employers who want to be ensured that immigrants have the communication skills needed to practise their professions.

Although the Canadian government has instilled programs such as the Language Instruction for Newcomers to Canada (LINC) which is part of the settlement programs, it has been said that it does not equip immigrants with a high degree of proficiency for the labour market (CIC, 2010). This will be expounded on further in the analysis section to see how instrumental these programs are in increasing the proficiency of immigrants to increase their productivity within the labour market since language is a vital aspect of human capital.

Another barrier to labour market access as it relates to language is the role of the accent, which is usually associated with pronunciation. One's accent can thus become a marker for economic discrimination, making their ethnic background more salient. Speaking with an accent can also be associated with non-native competence thereby leading to a negative evaluation by the mass, which further results in an issue of intelligibility (Munro and Derwing, 1999). Persons may have predetermined notions of how someone from a particular ethnic or cultural background may be when they hear their accent. This usually stems from a stereotype of the group, which can culminate in employment discrimination (Munro, 2003).

Although the use of a minority language can also gain employment access within one's ethnic enclave, this further inhibits the acquisition of the majority language and can have serious implications for the individual such as social isolation and reduced economic opportunities. One also has to question the types of jobs that are at the individual's disposal and if this enhances their upward social mobility. Couton (2013) concedes that an individual's ethno-racial group may lead to low-wage jobs and may foster dependency on some ethnic institutions for economic support. 
In addition to possessing sufficient knowledge of the host country's language, the type of social capital that one possesses and the more established they are, increases their chances of obtaining a job (Nakhaie and Kazemipur, 2013). The lack of effective social networking ties was also cited as a contributory factor to the underutilization of immigrants' skills (Reitz et al. 2014). Since many immigrants arrive to Canada without a social network which may include friends, family members or involvement in associations, employers often do not have anyone to officially 'vouch' for their characters or offer a professional recommendation on their behalf (Nakhaie and Kazemipur, 2013). Tyrrell (1999), affirms that this can minimize their entry into the labour market, as Canadian employers rely heavily on 'networking' as part of the hiring process.

\section{Employer's Hiring Practices}

Liu (2007) points to the disconnect that exists between employers' hiring practices and attitudes and the job search process of newcomers to Canada. With the advent of the 'knowledge economy' brought about by globalization and rapid developments in technology, this has brought about a similar need for more educated and skilled workers with higher levels of competency (Bill et al. 2003; Bambrah, 2005). As these factors form the human capital of a country, they are considered to be vital for economic growth and development (ibid.). It is reported that from 1986 onwards there has been a steady increase in the number of immigrants arriving to Canada with knowledge-based occupations especially from non-traditional countries. As cited by Bambrah (2005), this was propelled by changes in the structure of jobs in large corporations and the increment in the quantity of information. The point system was also adjusted to exclude arranged employment for independent applicants adopting more of a human capital focus (ibid.).

As a result of the changes that were also occurring in the employment sector in tandem with the increase in the number of immigrants, new job search strategies emerged which focused on 'credentialization' and 'networking' (Gurmeet, 2005). Bolles (2004) highlights the focus of hiring strategies in the new knowledge economy, which centred on qualifications and experience. As companies embarked on cost cutting job search strategies in the 1980s, the Bulletin Board System (BBS) also emerged.

These technologies resulted in a shift towards internet based recruiting which also gave rise to internal hiring within corporations via intranets. The BBS in conjunction with OCR scanners and 
web-based applications served to streamline the job application process making it easier for recruiters to sift out entire groups of applicants. This made it easier to identify job skilled immigrants for example who did not have the specific credentials requested, such as 'Canadian experience' and 'P. Engineer'. The restructuring of human resource practices thus served to create a divide between the potential job seeker and the employer, giving greater responsibility to the recruiter (ibid).

Informal job search processes which also emerged during this era, materialized through 'networking'. Tyrrell (1999) portrays that although the networking process also demanded the appropriate credentials, it also relied heavily on personal and professional networks. Saks (1994) states that companies preferred to use this method of recruiting than more formal channels, as it proved to be instrumental in reducing the rate of turnover thereby producing a better 'fit' for the organization. These recruitment strategies also served to reduce costs on the part of employers.

Shields et al. (2011b) concede that immigrants and the Canadian-born use similar methods to obtain jobs. It was reported however that immigrants in certain fields relied more heavily on the internet in their job search than their Canadian counterparts. This is reiterated by Bolles (2004) who juxtaposes the recruitment process of employers and the job attainment process of immigrants which lies in complete contrast. Whilst the number one option for immigrants is the use of their resumes, for employers, it is internal hiring. This is seen as a low-risk strategy for employers who are already familiar with the work of the persons they intend to contract. Preferred applicants include a present part-time employee, a former consultant or full time temporary worker.

Bambrah (2005) also refers to the 'Canada First' mentality as a way of denying newly arrived immigrants access to the labour market. The author gives the example of the Ontario Society of Professional Engineers (OSPE) which was created to protect the interests of professional engineers in Ontario. The organization has formally lobbied for employment preferences for Canadian graduates in light of an abundance of engineers in the field. Telephone interviews are another method of sifting out potential job seekers. This strategy is usually used by employers to decipher the language competency of the applicant and encompasses the first stage of the hiring process (Bambrah, 2005). In this instance the accent thus becomes a marker for discrimination 
and may serve to reinforce stereotypes against a particular social group resulting in a barrier to access to employment.

From the review of the literature I have outlined the factors that present barriers to access to employment for newcomers in order to analyze the post arrival assistance given to them in their job search. Although the background information is vital, my research will add to the literature by examining the content of the intervention programs to minimize the impediments faced by newly arriving immigrants and the risks involved in their job search. As previously referenced, the declining labour market outcomes of immigrants (Picot and Hou, 2003; Green and Worswick, 2002; Frenette and Morissette, 2005), their increasing poverty levels (Shields et al., 2011), differential access to employment compared to the Canadian born (Statistics Canada, 2009) and their failure to transfer human capital attributes to equitable earnings (Reitz, 2001) have been a source of concern for policy makers as well as for the Canadian public.

My rationale for undertaking this study is not only to highlight the continued systemic barriers that newcomers encounter in the job acquisition process, but also to examine the ability of socially inclusive projects within the area of employment, to minimize the economic exclusion of immigrants from the labour market. It is my hope that the findings of this research will shed light on aspects of the government funded employment programs that could be improved to better meet the needs of newcomers to Canada in the job attainment process.

The theoretical foundations that ground my research are social exclusion and inclusion. Social exclusion can be defined as "the dynamic process of being shut out fully or partially, from any of the social, economic, political or cultural systems which determine the social integration of a person in society (Walker and Walker, 1997 p.8). As cited by Byrne (2005), it can also be described as a "multidimensional process in which various forms of exclusion are combined: participation in decision making and political processes, access to employment and material resources and integration into common cultural processes" (p. 45), which subsequently result in unequal outcomes (Galabuzi, 2006). Social exclusion therefore reinforces social inequality and through its various dimensions such as racism, enhances the power dynamics of various groups within society (ibid.). As cited by Ann et al. (2009), social exclusion can be experienced on the micro, meso and macro levels arising from underlying social interactions. Micro level associations entail one's connection to their immediate family and the macro and meso levels 
pertain to relationships that develop outside the household and participation in external structures.

For newcomers to Canada, economic exclusion is often evident in their high levels of unemployment, underemployment and underutilization of skills (Reitz, 2001). Galabuzi and Teelucksingh (2005) have examined the effects of barriers to labour market access for immigrants and racialized people, who are highly concentrated into the lower segments of the labour market. These groups of individuals continue to experience income inequalities and are overrepresented in precarious employment. The authors reiterate the importance of job acquisition not only as a means of sustenance but also for the development of a 'sense of identity' and 'belonging'. Social exclusion in the job market therefore increases the isolation of the immigrant community and leads to further marginalization in housing, education, health care and social services (Galabuzi and Teelucksingh, 2010).

\section{Social Inclusion}

As cited by Galabuzi and Teelucksing (2010), social inclusion entails a society's widely shared social experience and active participation. Equality of opportunities and life chances for all are paramount as well as the provision of a basic level of well-being. It is achieved along a continuum where the values of all groups are esteemed with importance and individuals are given equal access to the labour market, housing and social services (ibid.). In an inclusive society therefore, everyone should be able to participate fully and should not be refrained from doing so based on a lack of "political or civil rights, employment or income or by ill-health or lack of education" (Askonas and Stewart, 2000 p. 154).

According to Askonas and Stewart (2000), "an inclusive society is a cohesive society" (p. 23) Social cohesion is therefore a necessary criterion for social inclusion. There must be a common consensus among the various members of society, based on shared norms and values that promote a national identity. Social cohesion therefore seeks to eliminate exclusion and enhance inclusionary measures (Galabuzi and Teelucksingh, 2010). In tandem, due to the changing ethnic and racial composition of the Canadian society, immigrant integration has become a more complex phenomenon and as such, efforts of social cohesion must be centred around notions of diversity, evident in the multiculturalism policy (ibid.). 
Askonas and Stewart (2010) question if a socially inclusive society can ever truly exist or if it is a mere utopia. A general consensus needs to be garnered around the contexts in which social exclusion is fostered and if these can be altered by socially inclusive projects. As cited by Byrne (2005), the intermediary measures applied, will be determined by the stance policy makers take and the views they hold regarding social exclusion. Solutions entail creating remedies to diminish the characteristics of the excluded individual that impede their progress within society and alternate measures focus on reducing the powers of the perpetrators of social exclusion. Either remedy adopted should take a holistic approach and examine all the causes of social exclusion given the context.

As reiterated by Askonas and Stewart (2000), a socially inclusive society does not exist in a vacuum or enter into being by merely reducing the factors which enhance exclusion such as 'racial discrimination', 'class inequality' or 'sexual prejudice' but inclusion requires 'mutual recognition' by all members of society working towards a common goal (p. 278). Despite various intervention strategies, newcomers to Canada have faced challenges to successful integration evident in their labour market participation, levels of unemployment and poverty in addition to inequitable gains for their human capital, which in turn has led to their spatial segregation and marginalization into ethnic enclaves (Galabuzi and Teelucksingh, 2010). 


\section{Chapter 2}

\section{Employment Programs and Services Available to Newcomers to Canada}

The employment programs analyzed in my research are part of the Government of Canada's and Ontario's settlement programs and are funded by Citizenship and Immigration Canada (CIC) and the Ontario Ministry of Training Colleges and Universities (MTCU) respectively. Previously the CIC's settlement initiatives were supported under the Settlement Adaptation Program (ISAP) since 1974, the Host program since 1984 and the language Instruction for Newcomers to Canada (LINC) program since 1992. In 2008 these services were amalgamated under one Settlement Program with a greater emphasis on outcomes (Smith 2010). Service Provider Organizations (SPOs) are now required to indicate how their projects will contribute to one of five expected results according to six activity streams (Seidle, 2010).

The goal of the Employment Related Services initiative under the Settlement Program is to provide newcomers with 'labour market access' and equip them with the necessary tools needed, in order to find and retain employment commensurate with their qualifications. Assistance is also provided to employers to obtain a qualified pool of newcomers to meet the needs of their organizations. Activities under this stream include bridging projects, job search help, skills training, workplace orientation and provision of labour market information (Smith 2010 p. 2). The Government of Ontario supports its settlement initiatives under the Newcomer Settlement Program which distributes its funding under two streams: Direct Settlement Services as well as Sectoral Support Projects. The 'Facilitate Finding Employment' category aims to provide indepth assistance to newcomers in finding a job and includes job counselling and training programs, job search strategies, form filling and access to computers (Lim, Lo, Siemiatycki and Doucet, 2005).

These employment programs and services are delivered through Services Provider Organizations (SPOs) and the range of services offered depends on the financial capabilities of SPOs and their manpower. Recent changes to funding however has had a negative impact on the day to day operation of the Settlement Sector and its ability to effectively provide services to newcomers (Evans and Shields, 2005; Richmond and Shields, 2004). The updated requirements for state financial assistance will be further explored in the analysis section. 
SPOs identified in my research include non-profit community based organizations, not-forprofit corporations, multicultural, multi-service agencies, educational institutions, ethno specific immigrant serving organizations and nongovernmental organizations that also cater to the needs of newcomers as well as the general public (See Appendix A). The Job Search Workshop and Employment Ontario Programs, which are the basis of my research, are funded by the CIC and the Ontario Ministry of Training Colleges and Universities accordingly. Additional employment programs are funded through private donors, corporate sponsors and various organizations such as the Ontario Trillium Foundation, which offers the Mentorship Partnership and the United Way of Greater Toronto (Lim et al. 2005).

The employment programs for newcomers that will be outlined in the following section fall under the following categories: Employment-related services, Bridge training services (regulated and unregulated professions), Mentoring programs, Employment Placement Programs and Language Training for Employment Support. These programs are administered by settlement agencies as part of their settlement services to newcomers to Canada, nongovernmental organizations classified as charitable institutions and organizations that assist job seekers facing barriers to employment to integrate into the Canadian labour market. These programs will now be explored in greater detail.

\section{Employment-Related Services for Newcomers to Canada}

As outlined previously, Employment Related Services is part of the Government of Canada's Settlement Program funded by the CIC. Activities under this stream provide newly arrived immigrants with assistance with their job search and to gain and retain employment. Programs explored under this category by Service Provider Organizations include: employment workshops, employment counselling and Job Search Workshops (JSW) and work placements. The range of services offered depends on the capacity of the agency to offer these services as well as their budgetary constraints. 


\section{Employment Workshops (See Appendix C for full description)}

Employment workshops assist newcomers to find employment in their field of expertise. Newly arrived immigrants are equipped with information about licensing, effective job search skills, Canadian employer expectations and workplace culture, the hidden job market, social networking, apprenticeship opportunities, staying employed and also provide information on self employment. Newcomers are also taught how to market themselves affectively and to identify and develop employable soft skills essential to the Canadian labour market and their career objectives. Workshop activities include interview preparation, cover letter writing and resume creation.

\section{Employment Counselling}

Newcomers are provided with employment counsellors that provide optimum solutions for their needs and make recommendations for their next steps. They also guide them during the job search process and refer them to other services. Employment counselling is usually offered by smaller agencies.

\section{Job Search Workshops}

Job Search workshops assist newcomers to better understand the Canadian labour market and job search procedures and in so doing aim to improve their employment outcomes. These workshops are based on the Government of Canada's Job Search Workshop model and delivered by Service Provider Organizations. This program is specifically designed for newly arrived immigrants who are job ready, have a certain level of proficiency in the English language and who are permanent residents, convention refugees or live-in-caregivers. Participants of Job Search Workshops have their career goals assessed and work with specialists familiar with the needs of newcomers. They also receive individual assistance and are able to participate in pre-employment workshops where they learn about job search strategies and Canadian business perspectives. (Job Search Workshop- www.jswontario.org).

Job Search Workshops are held over a two week period and delivered in two modules. Module one entitled 'Occupation Blueprint' equips participants with an understanding of Canadian workplace culture, the hidden job market and employer expectations. Individuals are also taught 
strategic networking techniques and how to employ social media in their job search. Resume formats in the Canadian context are also covered. Module two the 'Job Search' component provides an in depth understanding of various job search methods and newcomers are taught how to effectively market themselves using a targeted resume and cover letter. Participants are also equipped with skills on how to conduct a successful job interview and given the opportunity to engage in practice sessions (ibid.).

\section{Employment Ontario Program}

Administered by the Ministry of Training Colleges and Universities, the Employment Ontario Program provides jobseekers with the training, skills and experience needed to pursue their goals. The program entails an independent job search component through the use of the Resource and Information Area and a guided job search, which provides individualized assistance. Employment Ontario Resource Centres equip job seekers with information about different careers and occupations in Canada as well as those that are in high demand (Ministry of Training Colleges and Universities-www.tcu.gov.on.ca/eng/employmentontario). Individuals are also garnered with the necessary tools and skills in order to do an effective job search and can also participate in pre-employment workshops on resume development, interview practice and self marketing techniques (Acces Employment Services-www.accesemployment.ca).

Persons eligible to use the 'self-service information and resources assistance' provided by service partners include the unemployed, underemployed, those looking for work, students, apprentices and internationally trained individuals. The guided job search component of the Employment Ontario Program is for job seekers who face barriers to employment and their eligibility for participation is based on their education level, experience, skills, personal conditions and career goals and interests. Participants in the guided job search component are able to partake in job matching, placement and retention services and must be either unemployed or outside of school (ibid).

Additional Employment Ontario Programs and Services for Jobseekers (including newcomers) include the Second Career Option, the Ontario Self-Employment Benefit and assistance to Employers. The Second Career Option provides laid-off workers with skills training and financial support to pursue occupations that are in high demand in Ontario. Recipients are 
provided with a cost sharing grant that covers tuition expenses, instructional material and other living expenses. Unemployed individuals receiving employment insurance are eligible for the Ontario Self-Employment Benefit which gives financial and entrepreneurial support to persons wishing to establish their own businesses. Employers are able to obtain assistance with attracting qualified staff to meet their job requirements, advertise job postings and may also be eligible to receive financial incentives to offset training costs of employees (Ministry of Training Collegeswww.tcu.gov.on.ca/eng/employmentontario). 


\section{Bridging Programs}

The purpose of Bridge Training Programs in Ontario is to assist skilled newcomers to obtain their license or certificate in their profession so that they will be able to find employment commensurate with their qualifications. These programs are funded at the provincial and federal levels and are delivered by employers, colleges and universities, occupational and regulatory bodies and community organizations. Participants' education and skills are firstly assessed and they are then provided with 'clinical or workplace experience' and 'skills training or targeted academic training'. They also receive preparation for their licensing examinations and partake in occupation specific language training and referred to additional training programs as deemed necessary. Bridging programs also offer training in Canadian business culture and communication, networking and mentorship opportunities as well as employment support services. These include career planning, job search and development and job retention strategies. Successful completion of some programs leads to Canadian certification and equips participants with the necessary requirements for licensure such as the Early Childhood Education Bridging Program and the Bridge Training for Internationally Educated Pharmacists at Centennial College (Ministry of Citizenship Immigration and International Trade- www.citizenship.gov.on.ca).

Persons eligible to participate in bridging programs include internationally educated professionals with a post-secondary degree who are Canadian citizens, permanent residents or convention refugees. Participants can obtain bursaries through the Ontario Bridging Assistance Program offered by the Ministry of Training Colleges and Universities (Ministry of Citizenship, Immigration and International Trade- www. Citizenship.gov.on.ca). Bridge Training Programs are offered in a wide range of regulated and non regulated professions in Ontario. The table below outlines a range of these programs offered by their Service Provider Organizations. 


\section{Mentoring Services}

The Mentoring Partnership is a program of the Toronto Region Immigrant employment Council (TRIEC) and works in conjunction with employers and service delivery partners. The program connects skilled immigrants with established professionals in their fields that provide occupation specific information and advice and help them to advance their careers in Canada. Mentors also help newcomers to develop a network of business contacts, better understand the Canadian workplace culture and provide employment support in their industries (The Mentoring Partnership-www.thementoringpartnership.com).

\section{Additional Employment Support Services}

In addition to the employment programs and services stated above, additional employment support services offered to newcomers to Canada include online services such as Skills International.ca and language support services. Skills International.ca offers pre-screened internationally educated professionals the opportunity to connect with employers in their chosen fields. A database is created online with the newcomer's skills, experience and education where employers have access to qualified applicants who are ready to enter their professions. The advantage of this site is that it is dedicated exclusively to profiling the skills of Ontario's internationally educated professionals (www.skillsinternational.ca).

Occupation Specific Language Training (OSLT) offers newcomers to Canada who have previous training or experience in a particular field, the opportunity to learn sector specific terminology and improve their communication skills within the workplace. Participants gain a better understanding of Canadian business culture and are also provided with employment support. Occupation Specific Language Training is offered in the fields of Business, Health Sciences, Human Services, Construction, Technology and Automotive Trades. 


\section{Basis for Research}

The employment programs presented above portray the wide array of services available to newcomers to Canada in their job search and the assistance given to them to enter the labour market. In my analysis, I have decided to focus on Job Search Workshops, a program developed by Citizenship and Immigration Canada and the Employment Ontario program. As portrayed above, Job Search Workshops fall under the Government of Canada's Settlement Program as part of Employment-Related services. In an evaluation done by the federal government in 2005 of this service, focus group participants expressed that "employment services were insufficient to help them get jobs" (Citizenship and Immigration Canada, 2005 p. 6). While newcomers were appreciative of workshops on resume writing, interviewing techniques and job searching, many confessed that these services did not play a major role in job attainment and skilled immigrants indicated that this service was too basic.

Findings from the study commissioned by OCASI (2012) indicate that most immigrants tend to use employment services within their first year of arrival. In assessing immigrants' satisfaction of employment and skills training programs and services which include the programs outlined above, respondents expressed a greater level of satisfaction with self-employment or business development programs/training (72.8\%) followed by skills upgrade programs (67.7\%). With reference to the employment and skills training programs and services, while 58.3\% of respondents indicated that these programs had equipped them to better understand the Canadian workplace culture, only $31.9 \%$ of newcomers revealed that these services had helped them to obtain employment (OCASI, 2012 pp. 41-43).

Since program participants highlighted the insufficiency of Employment-Related services to provide them with labour market access, in my analysis I examined the components of the Job Search Workshop to verify how the employment needs of newcomers are met through its program offerings and the goals of this service. A similar objective was embarked on through a content analysis of the Employment Ontario Program and how it assists newcomers to overcome barriers faced in labour market access according to the goals of the service. 


\section{Chapter 3}

\section{Analysis and Findings}

The job search workshops of 10 service provider organizations were analyzed which included non-profit community based organizations, multicultural and multi-service agencies, non-profit organizations and ethno specific agencies. This information was gathered from the Job Search Workshop Ontario site (jswontario.org). The content of the workshop was analyzed against four factors, which represent the major barriers to access to employment for newcomers to Canada garnered from the review of the literature.

These factors include: the accreditation process, the use of discriminatory hiring practices (non preference for foreign credentials, Canadian experience, discrimination based on foreign origins and racial or ethnic backgrounds), the personal conditions of newcomers based on their human and social capital and employer's hiring strategies such as internet based recruiting, internal hiring, 'Canada First' mentality and the use of telephone interviews as a screening process. The organizations that administer the Employment Ontario program were also selected from the Employment Ontario website (www.employmentontario.org) and their content analyzed using the same methodology as the Job Search Workshops.

The analysis of the Job Search Workshops included print material garnered from the organizations themselves, such as program brochures and flyers and information from the company website including their annual reports from recent years. Results indicate that the vast focus of Job Search Workshops is on the recruitment strategies of employers. While not specifically focused on identifying the hiring strategies of employers that pose a barrier to access to employment for newcomers, $100 \%$ of the published material reveal that the activities in this category are more in alignment with 'pre-employment preparation'. Participants of Job Search Workshops gain an understanding of Canadian workplace culture, the hiring practices of employers, which include 'the hidden job market' and internal hiring, resume and cover letter preparation according to Canadian standards and effective job search strategies. Individuals also obtain career specific knowledge and information on the labour market and develop effective interview techniques. 
With regards to employees' personal conditions as a barrier to access to employment, $70 \%$ of the published material analyzed, reveal that the dominant focus is on developing social networking ties. Participants are taught the importance of building professional networks and where and how to do this. With regards to discrimination as a barrier to access to employment for newcomers, $10 \%$ of the content of Job Search Workshops is focused on Canadian experience as a means of overcoming this barrier. Pre employment preparation under this category includes work experience placements and evaluating experience in Canadian terms.

Analysis of the Employment Ontario Program reveals similar findings. One hundred per cent of the published material portray that there is an overwhelming focus on pre employment preparation, which includes effective job search strategies, resume writing and interview skills, understanding the Canadian labour market and how to market yourself to employers. Eighty per cent of the published material reveals strategies on how to combat discrimination as a barrier to labour market access for newcomers. Newly arrived immigrants are provided with unpaid volunteer work placements, job development and placement support, post employment support if required and subsidized employment. Apprenticeship opportunities are also provided as well as on the job training and trials.

With regards to improving employees' personal conditions such as language and social capital, which may pose as barriers to labour market access, $60 \%$ of the published material is focused on networking as a tool to build professional ties and mentorship opportunities that provide newcomers with occupation specific information and advice. Training on workplace communication skills is also provided. In the area of accreditation, $1 \%$ of the published material reveals minimal strategies on how to diminish this factor as a barrier to labour market access for newcomers. Assistance employed includes marginal guidance on professional licensing and certification.

The major focus of Job Search Workshops and the Employment Ontario program on resume and cover letter writing, according to Canadian standards, may be to better understand the hiring strategies of employers in terms of current technology used by companies. As observed by Gurmeet (2005) and as previously cited, the advent of the Bulletin Board System in conjunction with OCR scanners and web-based applications not only made it easier for recruiters to sift out entire groups of applicants but also had a direct impact on the immigrant community. Individuals 
who did not possess the specific credentials requested such as 'Canadian experience' were also more easily identifiable.

As previously referenced, while it is vital for the newcomer to make himself more marketable through the use of a refined resume and cover letter appropriate to 'Canadian standards', this does not guarantee a call back from an employer as various factors may come to the fore when selecting a candidate for an interview. Guided by their own efforts to ensure a successful hiring process in tandem with individual manager's preferences, according to Oreopoulos \& Dechief, (2011), "subconscious beliefs and attitudes may influence assessments and decisions nonetheless" (p. 23).

As a previous participant of the Employment Ontario program, I was given the opportunity to participate in a job placement with a Canadian organization for a duration of three months. While I gained greater insight of the Canadian workplace culture, I later discovered that the time spent at this company was deemed insufficient in order to obtain another job opportunity. While these programs provide access to the labour market, I believe that the type of work experience garnered is equally important as this can have a further impact on the individual's employment trajectories to be fully integrated into the labour market and gain stability.

\section{The Accreditation Process: One of the greatest barriers to Immigrant labour market Access}

The accreditation process is one of the areas in which the newcomer faces significant obstacles in the provision of labour market access to (Bauder, 2003; Teelucksingh \& Galabuzi, 2005). As previously referenced in the review of the literature, differentiated measures are often imposed on Canadian-educated workers as opposed to foreigners. In the medical profession for example, the majority of the residency positions are allocated to Canadian graduates (Ibid.) Newcomers to Canada also usually do not receive adequate information before and after arriving about the licensing process. Teelucksingh \& Galabuzi, 2005 also declare that the accreditation process is not very transparent and there is a lack of feedback and appeal process.

Even after being certified and receiving the required credentials, skilled immigrants may still face biases from employers who question their possession of 'soft skills' such as adaptability and communicative competence. This leads to the underutilization of the newcomers' skills due to 
the employer's discriminatory hiring practices of the foreign credential not being accepted, even after it has been formally recognized (Reitz, 2001a). Teelucksingh \& Galabuzi, (2005) refer to the impediments associated with the licensing process as the 'racialized experience of barriers to access to professions and trades' (p. 28), which not only amounts to financial but also emotional costs to the immigrants and their families.

Analysis of the Job Search Workshops and Employment Ontario Programs indicate that minimal information exists about the accreditation process and ways to overcome the impediments experienced by newcomers. Marginal guidance is offered on professional licensing and certification as well as credential assessments. (See Appendix B). Being that the accreditation process is one of the areas in which the newcomer faces numerous challenges, I believe that greater intervention strategies need to be instilled especially during the pre-arrival phase. Newly arrived immigrants in the regulated professions need to be equipped with the right information from staff knowledgeable about the process. Although different intervention strategies have been put in place at the federal level to ensure greater transparency, Teelucksingh and Galabuzi (2005) remark on the limited coordination that exists between the various stakeholders.

\section{Effective Social Capital}

Analysis of the Job Search Workshops and Employment Ontario programs also indicate that there is a heavy focus on building professional networks. Workshops and other job related activities include information on where and how to network as well as the importance of networking and networking tips (See Appendix C). The type of social capital that one possesses and the more established they are increases their chances of obtaining a job (Nakhaie and Kazemipur, 2013). Since many immigrants arrive to Canada without a social network, which may include friends, family members or involvement in associations, employers often do not have anyone to officially 'vouch' for their characters or offer a professional recommendation on their behalf (ibid). This can minimize their entry into the labour market, as Canadian employers rely heavily on 'networking' as part of the hiring process (Tyrrell, 1999).

The lack of effective social networking ties was also cited as a contributory factor to the underutilization of immigrants' skills. The difficulties associated with obtaining professional 
references for internationally trained professionals as well as evaluating their international experience (Oreopoulos \& Dechief, 2011), may influence a preference for hiring those with Canadian based resumes. As some employers have indicated a preference for gravitating more towards what is 'familiar' (ibid.) to them in the hiring process, it is evident that not possessing effective social capital can serve as a hindrance to access to employment in the Canadian labour market.

\section{Funding Issues}

In examining the employment programs and services offered to newcomers to Canada and their ability to provide labour market access to recent immigrants amidst the barriers experienced, it is also imperative to look at the ability of Service Provider Organizations (SPOs) to administer these services. As cited by Sadiq (2004), the settlement of immigrants and refugees in Canada as mandated by the CIC, falls under the purview of the federal and provincial governments as well as the not-for-profit sector. It endorses its programs through Service Provider Organizations, which include community based, or ethno-specific organizations as well as non-governmental organizations (NGOs).

Previously the CIC structured most of its funding for newcomer services around three main programs: the Immigration, Settlement and Adaptation Program (ISAP), Language Instruction for Newcomers to Canada (LINC) and the Host Program. In 2008 the CIC developed a modernized approach to its settlement programming which had a greater emphasis on outcomes. Service Provider organizations are now required to indicate how their projects will contribute to five expected results based on six stipulated activity streams (Seidle 2010).

Even though the Settlement Program was designed to be more "responsive and flexible to meet clients needs" (Smith 2010 p.1), some SPOs do not possess the resources or manpower to efficiently deliver newcomer services. Under labour market access for example, newly arrived immigrants obtain the necessary assistance to find employment commensurate with their qualifications. Job related services equip newcomers with the required skills to 'search, gain and retain employment' (ibid. p. 2). Results of my analysis indicate however that the range of programs offered in this field is also dependent on the size of the organization. Some Immigrant Serving Agencies (ISAs) for example are only able to provide newcomers with counselling 
services while the larger ISAs may offer job placements and bridging programs (City of Toronto http:www.211toronto.ca).

Although SPOs now have greater flexibility under the Settlement Program as instilled by the CIC, some ISAs are still limited in their function to deliver these services. The Job Search Workshops (jswontario.org) and Employment Ontario Programs for example are administered directly by the CIC and municipal governments respectively. Funding for newcomer programs by the Government of Canada is now provided through purchase of service agreements (Sadiq 2004), which have become competitive in nature (Richmond \& Shields 2004). SPOs then may be hindered in their creativity due to lack of capital and human resources, thus becoming mere executors of state financed projects to the immigrant community.

Service Provider organizations have also been hindered in their day-to-day operations, as a result of government underfunding. This is very detrimental to the viability of the non-profit sector as $60 \%$ of their operating capital is obtained from state financing (Evans and Shields 2005). In addition to cuts to their operating capital, as cited by Shields, 2003, a shift from 'core' or base funding to 'contract funding' of a short term nature also occurred, which requires purchase of service agreements with specified outputs and increased accountability measures. This new arrangement also allowed governments to control spending and reduce supposed inefficiencies of non-profit organizations creating a tighter reign on the industry (ibid.).

In tandem with the way in which funding is currently administered, the federal and provincial governments also sought to minimize their involvement in the delivery and support of settlement services by devolving its administration to the provinces as well as the not for profit sector (Sadiq 2004). This approach has been described as 'neoliberal' in nature with the contracting out of newcomer services and the adoption of a more entrepreneurial approach with SPOs. According to a neoliberal logic, excessive social support and spending foster a relationship of dependency and in this regard the curtailing of funding to settlement services has also been seen to be justified (Shields 2003). 


\section{The Changing Role of NGOs}

The neoliberal approach to the delivery of newcomer services is also reflected in the increasing role of nongovernmental organizations considered as 'agents of the state' in the provision of settlement services. As posited by Evans and Shields (2005), the partnership developed between the government and non-profit sector has transformed the focus of NGOs from that of advocacy and community development to the administration of programs provided by the state. This has placed a further strain on the relationship between the various SPOs, as Immigrant Serving Organizations now have to vie for government contracts. The increased competition for state grants has therefore created a 'shadow economy' in which smaller community organizations have to depend on bigger corporations or NGOs and enter into multipartnership projects. As the bigger non-profit organizations have the staff and wherewithal to cater to an increase in demand for services for a growing newcomer population, they are better able to meet the stipulations for funding. They are also better able to adjust their operations and remain afloat amidst the restructuring of the industry (ibid.).

Larger ISAs tend to be the securers of government contracts since they possess the resources and organizational capacity. These agencies in turn contract out their services to smaller ISAs who often have to co-locate with larger multi-service providers creating what has been termed by Sadiq (2004) as a 'spatial mismatch' between the demand for newcomer services and the supply of these services. This relationship of dependency not only compromises the viability of smaller ethno-specific ISAs but also hinders their autonomy and ability to competently serve particular groups of immigrants that may have specific needs (ibid.). The reduction in funding has thus had more of a negative impact on smaller community based organizations that have not only had to reduce the amount of services offered but also had to close their doors (Evans and Shields 2002).

Not only did SPOs undergo cuts in funding for settlement services, but the province of Ontario also experienced a reduction in financial assistance from the federal government. Funding is currently provided based on the number of newcomers in each province and territory (CIC 2011). The change in settlement patterns of newly arrived immigrants to Canada as well as a decline in the percentage of newcomers to Ontario and moreover to Toronto, has resulted in a reduction in provincial financing for its settlement programs and services. According to the former Minister of Citizenship, Immigration and Multiculturalism, Mr. Jason Kenney, "the 
number of newcomers choosing to live in Ontario has fallen by $24 \%$ from 141,000 in 2005 , to 106,000" (Kenney 2011) despite a previous increase in funding under the Canada Ontario Immigration Agreement (CIC 2011a). The decision was therefore made in 2011 to reallocate monies away from the overfunded provinces, in an effort to make state financing of its settlement services more equitable (ibid.).

With the devolution of settlement services to the 'third sector' and the growing monopolization of operations by nongovernmental organizations, the future of settlement services has now become a salient issue as well as who has the ultimate responsibility for the provision of these services. In January 2015, the Express Entry System, as a pathway to permanent residency in Canada was introduced. This new immigration policy was designed to improve the economic outcomes of immigrants as well as reduce the current backlog (Ferrer, Picot \& Riddell 2014). Applicants complete an online profile based on certain qualifying factors according to the federal immigration program selected. Candidates in the pool who score the highest points based on human capital criteria are then asked to apply.

Even though employers have the opportunity to make job offers to applicants in the preselection process, they are required to submit a Labour Market Impact Assessment (LMIA), which may subject them to lengthy and cumbersome bureaucratic procedures. Applicants will also be awarded additional points for a job offer supported by an LMIA or a nomination by a province or territory, which increases their likelihood of being invited to apply for the next stage of the process (Citizenship and Immigration Canada- Express Entry). Based on the aforementioned information, it appears that employment is now the central focus in the selection of economic immigrants to Canada. This leads to the question of who will now be responsible for the provision of settlement services to newcomers as well as the future of the economic immigration system. Will settlement service delivery now be devolved to employers who extend job offers to potential applicants? In addition will they also be responsible for providing other job related services to newly arrived immigrants such as occupation specific language and skills training, employment counselling and workplace orientation services currently provided by Immigrant Serving Agencies?

A primary objective of the CIC is to "support the settlement and integration of newcomers to Canada" (CIC 2010). The devolution of responsibilities to the Settlement Sector however does 
not reflect this role. Recent changes and decrease in government funding for newcomer services, as well as to childcare, public housing, language training and employment training and job placements (Evans and Shields, 2005) leads one to also speculate if there will be further cuts and who will now be in charge of funding. In the concluding section I will undergo further exploration as to the factors which foster immigrant success in the labour market from both a scholarly and employers' perspective, examine the overall issues that are not being addressed by the Job Search Workshop and Employment Ontario Programs and make recommendations as to what can be implemented with regards to barriers to labour market access for newcomers.

The theoretical foundations examined, portray the various ways in which newcomers to Canada suffer from social exclusion (Galabuzi and Teelucksingh, 2010). In response to this, public policy in Canada has been seen to focus on the excluded, to alter their handicapping attributes and bring about inclusion (Byrne, 2005). Askonas and Stewart (2000), posit that in a socially inclusive society everyone has access to its central goods and fair opportunities. It would therefore not be characterized by high levels of unemployment, poverty or income inequality. This is not always the case however as social exclusion has many different dimensions such as gender, race, religion, disability and sexuality (ibid.).

\section{Connecting the Dots}

With respect to the field of employment, as cited by Askonas and Stewart (2000), job acquisition does not equate to social inclusion as having mere access to the labour market does not guarantee that one will not be economically disadvantaged. The quality of the job must also be examined which can inherently help to widen the earnings gap and further promote social exclusion. If previously unemployed people are only able to obtain low paying 'survival' employment then this hinders their social mobility and increases their marginalization (ibid.). This is portrayed in the 'deskilling' process particularly of skilled workers to Canada as previously referenced, as a result of the formal and informal barriers posed, which is particularly evident in the accreditation process and amounts to 'brain waste' (Bauder, 2003). In many cases newly arrived immigrants have to accept lower status jobs for which they are overqualified or eventually abandon their previous professions as a result of difficulties of obtaining licensure (ibid). 
The Job Search Workshops and Employment Ontario programs can be seen as socially inclusive projects to provide newcomers with access to the labour market. Citizenship and Immigration Canada is cognizant of the systemic barriers faced by newcomers to Canada and has through its programs, sought to address these issues. It supports the settlement, resettlement and integration of newcomers into the society and assists them to become "active, connected and productive citizens" (Citizenship and immigration Canada, 2012 p. 1).

With further reference to the policies implemented for job acquisition, Askonas and Stewart (2000) comment on the notion of 'employability' which is also inherent in the goals of the JSW program. This entails garnering individuals with a range of skills and experience to make them more adaptable to a changing labour market and gain access. The authors comment on the erroneous assumption of this approach to see the individual deficiencies of the individual as the primary barrier to job attainment, instead of systemic or macro factors. Governments who adopt this model therefore embark on policy initiatives to correct these personal inadequacies such as further education and training, job subsidies and work placements and programs designed to develop 'soft skills' (ibid.).

Askonas and Stewart (2000) assert that macro economical and structural changes in the labour market also need to occur in order to reduce the level of unemployment and not merely increasing the 'employability' of individuals. This reiterates the review of the literature that employment services which include resume and cover letter writing as well as interview preparation was the least successful method of job acquisition whilst those that included a work placement component were better able to meet the economic needs of individuals. While the major focus of the JSW and Employment Ontario Programs are on employment preparation and understanding the Canadian labour market, there needs to be an equal focus on the systemic barriers that are pervasive and have even dire consequences for social cohesion. Askonas and Stewart (2000) further declare that high levels of unemployment not only has a positive correlation on poverty levels but can also lead to health related issues and social isolation. 


\section{Conclusion, Discussion and Recommendation}

The decline in the economic circumstances of recent immigrants to Canada has been reflected in their higher rates of unemployment, lower earnings and lower labour force participation, which has been reported to be persistent (Grant and Sweetman, 2004). The underutilization of immigrants' skills not only results in lost earnings (Reitz, 2001a) but also in 'brain waste' (Bauder 2003). Various factors affect employment for newcomers of which include their human capital endowments, national origin, ethnicity or race, social capital, discrimination, credential recognition and area of settlement within Canada (Reitz, 2007).

Citizenship and Immigration Canada (CIC) recognizes the role that systemic barriers play in the attainment of employment for newcomers and has through its labour market access program, sought to address some of these issues (CIC 2012a). Four major barriers to access to employment for newcomers ascertained from the review of the literature include the accreditation process (Bauder, 2003; Galabuzi and Teelucksingh 2005), racism/discrimination based on foreign origins and credentials (Bauder, 2003; Gurmeet, 2005), employee's personal conditions (Alboim et al. 2005; Picot and Sweetman, 2012; Aydemir and Skuterud, 2005) and employer's hiring strategies (Liu, 2007; Ahamad et al. 2003; Bambrah, 2005). The Job Search Workshop funded by the CIC and the Employment Ontario Program funded by the provincial government were analyzed, to ascertain the aspects of these programs that address these barriers.

Results indicate that there is a heavy focus of both programs on employers' hiring strategies. Activities to overcome this barrier include resume and cover letter writing and interview skills, job search methods, labour market information, Canadian workplace culture and employment focussed workshops. Practical examples include cold calling (JSW Evaluation Report, 2012) and preparation for informational interviews (personal knowledge- JSW workshop). With regards to Employee's Personal Conditions such as social and human capital attributes as a barrier to access to employment, activities of both programs were centered around social networking skills, with the aim of building professional contacts. In order to combat discrimination against foreign origins and immigrant status, the attainment of Canadian experience was the central focus of both the JSW and Employment Ontario Programs, where participants engaged in paid and unpaid work placements. The least focused on area was the accreditation process with $1 \%$ of the 
published material citing evidence of marginal guidance provided by Immigrant Serving Agencies on professional licensing and certificates.

Reitz (2007) posits that the way in which immigrants are responded to within labour markets is affected by such factors as 'overall labour demand within specific occupational and industrial sectors' (p. 12), among others. The supply of labour from both immigrants and native-born workers at different skill levels also come into play (ibid.). The selection process for independent applicants based on human capital criteria (Reitz, 2007), has been criticized for not adequately reflecting the needs of small and medium sized enterprises (SMEs) in the area of trades, or meeting the demands of the Canadian labour market (Debus, George and Petkov, 2008; Bill et al. 2003). Results of a survey undertaken by the Canadian Federation of Independent Businesses (2008), indicate that $42 \%$ of labour shortages that occur in SMEs are in the skilled and technical category, whilst professional and managerial positions only account for $8 \%$, of which the majority of economic immigrants fall.

In addition to the inability of the current immigration system to adequately meet the needs of small and medium sized enterprises, over 50\% of SMEs identified language as the number one most cited problem, encountered with the integration of immigrants into the workplace. Other challenges included those of an interpersonal nature due to cultural and religious differences and the evaluation of foreign credentials (ibid.). The accreditation process is considered as one of the areas which presents a myriad of challenges to access to employment, for newly arrived immigrants. In the first instance, the licensing system has been said to exhibit preferential treatment for applicants who were educated in Canada, evident in the difference in costs for newly arrived immigrants and the native born. The process has also been described as 'culturally biased' and 'exclusionary' in addition to being time consuming and costly (Bauder, 2003).

With specific reference to the Job Search Workshop and Employment Ontario programs, results indicate that the licensing procedure is the least focused on area and that activities of both services further correspond to increasing the employability of participants and making them more 'job ready'. A common consensus among newcomers is that while Employment Services were instrumental in equipping them with resume writing skills and job search and interviewing techniques, it did not grant them labour market access. These activities were also considered too elemental for skilled immigrants (CIC, 2005). In another study commissioned by OCASI (2012), 
respondents indicated greater satisfaction with self-employment or business development programs and training opportunities, followed by skills upgrade programs.

As cited by Galabuzi and Teelucksingh (2010), the various challenges that immigrants experience in their successful integration into the Canadian society amount to social exclusion. This has been evident in their labour market participation, unemployment levels, employment and income attainment relative to human capital endowments, poverty levels and spatial segregation and exclusion to ethnic enclaves. Social cohesion strives to eliminate social exclusion and bring about social inclusion. Its goal is social solidarity based on shared values, common norms and common bonds (ibid). It therefore refers to the "capacity of society to set and implement collective goals" (Reitz and Banerjee, 2007 p. 17).

Racial discrimination and marginalization of various groups within a society may have an impact on its cohesiveness and lack of unity and thereby inhibit efforts of inclusion. Reitz and Banerjee (2007) point to evidence of various levels of inequality experienced by visible minorities within Canada. Such examples include lower household income and higher poverty rates. Efforts of cohesion are further compounded when dominant groups actively seek to hinder the opportunities of others in areas such as employment, housing and vital social services. Racial discrimination not only slows the process of social integration down but also has an adverse effect on the level of trust and Canadian identity for visible minorities which has a further impact on social cohesion (Reitz, Breton, Dion, Dion, Phan \& Banerjee, 2009).

As cited by Reitz and Banerjee (2007), the pervasiveness of racism in the Canadian society is a very moot point, as there is a prevailing view that its existence is merely minimal and does not significantly hinder the opportunities of the immigrant community. Evidence cited from the Ethnic Diversity Survey however, reveal that discrimination has been experienced on a larger scale by racial minorities, of which many recent immigrants to Canada fall (ibid.). In addition to foreign origin and immigrant status as a proxy for employment inequality (Galabuzi and Teelucksingh 2010), race also plays an influential role in access to the labour market and professional advancement. Discrimination was found to be more prevalent within the workplace and reported to be at play by $20 \%$ of visible minorities when applying for a job or promotion (Reitz et al. 2009, p. 129). 
While discrimination can prove to be a difficult feat to overcome, initiatives at the national level have been instilled to establish a forum for dialogue and to shed light on these issues. Policy initiatives have been considered to be minimal in nature and further compounded by the fact that racism within the Canadian milieu has been viewed by some as mere 'perceptions' and marginally existent (Reitz and Banerjee, 2007). In this regard, organizations such as the Canadian Race Relations Foundation as well as government advisory councils and panels, were created to help to eliminate racism and strive towards racial harmony. It has been stated however that policies which focus on minority inclusion have been limited in scope and nature and that greater accountability measures need to be instilled (Reitz et al. 2009).

In an attempt to address the issue of social cohesion within the Canadian society, the multiculturalism policy was created in 1971. Diversity and recognition of various ethnic groups is fostered and newcomers are encouraged to maintain their cultural heritage. It has been argued though that multiculturalism reinforces the marginalization of minority groups and presents a threat to Canadian identity. The policy has also been criticized for being too ceremonial in its approach and not adequately addressing the systemic inequalities faced by minority groups within society. In addition, as social justice is one of its goals, equal opportunities in different domains should be more emphasized (ibid.).

The accreditation process has been cited as one of the areas in which newcomers to Canada have faced increased barriers to access to employment. Practices of regulatory bodies have been described as vague and non transparent and lack adequate licensing tools to comprehensively understand the credentials of newcomers (Teelucksingh and Galabuzi, 2005). Coupled with the paucity of information pre and post-arrival (ibid.), newly arrived immigrants to Canada have faced the added challenges of lack of bridging opportunities, requirement of 'Canadian experience' as part of accreditation procedures, less access to financial aid and greater expenses compared to domestic applicants. Although the Office of the Fairness Commissioner was established in 2007 to remove the barriers encountered in the credential assessment process, making it 'transparent, objective and impartial' (Reitz, 2014), newcomers to Canada still face a competitive disadvantage (Office of the Fairness Commissioner, 2013). The problems encountered in the accreditation system points to the lack of coordination that exists between the 
provinces and the professional associations which needs to be greater regulated by the federal government.

Linguistic adaptation was cited as one of the greatest difficulties encountered by newly arrived immigrants to Canada, four years after arrival (Schellenberg et al. 2007). Language has also been used as a marker for employment discrimination and a barrier for labour market access. Telephone interviews are often used to determine the language competency of applicants and as a sifting mechanism in the hiring process (Bambrah, 2005). The 'accent' can also be used as a discriminatory measure to reinforce stereotypes against a particular ethnic group and to decipher their level of competence (Munro and Tracey, 1999) (Munro, 2003).

The communicative ability of newcomers is still a major area of concern for employers and although the Government of Canada provides language instruction under its Settlement Program, evaluation results have indicated their insufficiency for the labour market (CIC, 2010). Although policy initiatives have stipulated a higher level of language proficiency for newly arrived immigrants (Citizenship and Immigration Canada), I believe that greater emphasis should be placed on occupation specific training.

The employment programs examined in this research highlight the complex nature of the job acquisition process for newcomers to Canada. The Fair Trading Commission has reiterated the importance of bridging programs especially for the regulated professions. While the JSW workshops have proven effective in increasing the employability of newly arrived immigrants making them more culturally competent and knowledgeable, the resounding view is that it does not assist participants to get jobs (CIC, 2005; OCASI, 2012). Although the Employment Ontario Program incorporates a placement component and works closely with employers, participants firstly have to demonstrate that they are facing barriers to employment (Ministry of Training Colleges and Universities). In addition, internship opportunities may not specifically be aimed towards a job in their field but merely to gain access to the labour market (personal knowledge). Programs with bridge-to-work experience and mentoring services on the other hand were deemed more successful but were inadequate to meet the demand of applicants (Fairness Commissioner, 2013). 


\section{$\underline{\text { Successful Initiatives }}$}

\section{The TRIEC Model}

The Toronto Region Immigrant Employment Council (TRIEC) has been recognized for its stellar achievements in helping immigrants to overcome the barriers to access to the Canadian labour market and works to create opportunities in order to better integrate skilled immigrants in the Greater Toronto Area, into their field of expertise (Toronto Region Immigrant Employment Council-triec.ca). Recognizing the persistent problem of the underutilization of newcomers' skills, TRIEC collaborates closely with employers, educational institutions, regulatory bodies, community organizations, assessment service providers and all three levels of government among others, to involve the private sector to try to fill this gap (Reitz, 2014; Birrell and McIsaac, 2006).

In addition to work experience and employment preparation services offered by other job search entities, TRIEC offers a holistic range of programs to cater to the myriad challenges faced by skilled immigrants in Canada. These include The Mentoring Partnership, Professional Immigrant Networks (PINs) and a website geared towards helping immigrants succeed- Hire Immigrants.ca. Through a concertive effort with employment service providers, TRIEC matches immigrants with established professionals in their field who serve as mentors (Toronto Region Immigrant Employment Council- triec.ca). During the mentoring relationship mentees obtain advice on their chosen profession, employment preparation and are then connected to a network. The program has been successful in resolving the social capital dilemma faced by newly arrived immigrants and $68 \%$ of participants have found a job directly into their field (Birrell and McIsaac, 2006).

Through its Professional Immigrant Networks (PINs) program, TRIEC works with a range of employers, professional associations and other stakeholders to further provide immigrants with networking opportunities. It also caters to employers by providing them with learning opportunities and helping them to develop a more diverse and inclusive workforce. In addition to this, the hireimmigrants.ca portal was established to provide organizations with information on how to recruit and retain an immigrant pool as well as to promote their value and expertise to human resource officers. Other initiatives include building awareness about the wasted talent of 
newcomers and creating strategic alliances with key stakeholders to better integrate newly arrived immigrants into the Toronto Region labour market (triec.ca).

TRIEC has been instrumental in bridging the gap between the private sector and its immigrant clientele as well as raising awareness about immigrant expertise. It obtains funding from all three levels of government as well as charitable foundations that also play an organizational role. A significant amount of its capital is also generated from the private sector (Birrell and McIsaac, 2006). In order to influence public policy, an Inter-governmental Relations committee (IGR) was formed which serves as a forum for government actors to convene, share information and develop optimal solutions.

TRIEC differentiates itself in its practical approach to reducing the barriers faced by employer's hiring strategies and attitudes and in so doing dedicates all of its efforts to lobbying and creating opportunities for a diverse workforce where the skills and expertise of immigrants are efficiently utilized. It aims to promote long term solutions to integrate newcomers into the Canadian labour market and obtain meaningful employment by educating employers on how to recruit, retain and attract foreign educated professionals and empowering skilled immigrants (triec.ca). The organization faces challenges to funding like any other immigrant serving agency but seeks to employ donors who also want to see a change for the Greater Toronto Area.

\section{$\underline{\text { Conclusion }}$}

Reitz (2014) affirms that immigrant skill underutilization in Canada persists and has also deteriorated. While this group of individuals has increased in numbers, their access to professional level employment has been limited. The devaluation of the skills of newcomers has led in some cases to income inequality with native-born Canadians. The literature examined in this research persistently shows that the systemic barriers of the accreditation system and racial discrimination to a greater extent, have impacted the job opportunities of newly arrived immigrants. Results from the labour market programs examined in this study indicate that these are the least focused on barriers but should be garnered more attention.

The fact that each certifying body has its own qualifications and evaluation procedures adds

to the complex nature of the licensing process. The non regulated professions also rely heavily on academic certifications and the use of analytic and problem solving skills (Reitz, 2014). This 
is further perpetuated by the non-recognition of immigrant qualifications by employers even after the credential has been accredited (Bauder, 2003; Reitz and Banerjee, 2007). As previously referenced, some organizations have also adopted a 'Canada First' mentality (Liu, 2007) in their hiring strategy, which can unconsciously lead to employment bias. Hiring personnel have expressed the need to stick to the 'familiar' (comfort factor) when opting to hire Canadians so that they will have a better 'fit' (Oreopoulos 2009 pp. 17, 39). These practices lead to employment discrimination and hinder the opportunities of newcomers for labour market access.

Although Canadians are generally supportive of immigration (Banerjee and Robson, 2009), there is a clear existence of 'racial boundaries' within the society. This is evident in the stated preference of interaction with minorities of European origin within certain social settings (Reitz and Banerjee, 2007). As race and national origin further play a role in the assessment of qualifications or professional competence, this further compounds the problem (Reitz, 2014). This leads to the question and possibly for further research, if government interventions for immigrant employment can adequately provide newcomers with labour market access amidst the barriers to job acquisition. According to OCASI (2012), participants expressed greater satisfaction with skills' upgrade programs and bridge training for internationally trained professionals. The paucity of these programs however and issues of funding have made it difficult to meet the demand (Office of the Fairness Commissioner, 2013).

Other organizations have embarked on leading employer culture change (Toronto Region Immigrant Employment Centre- triec.ca) or working closely with human resources personnel to avoid employment bias (Oreopoulos, Walker \& Omidvar 2015). The value of diversity has also been promoted with the benefits of profiting from hidden talents and new perspectives from other nationalities (RBC Financial Group, 2005).

Reitz and Banerjee (2007) assert that the settlement patterns of immigrants also contribute to their employment difficulties as they tend to settle in urban areas where there is increased competition from the Canadian born who are also new to the job market. While suggestions have been made for newcomers to move to the more unpopulated and less metropolitan areas of Canada, integration services remain a challenge (Wang and Truelove, 2003; Lo et al. 2010), in addition to connecting with their ethnic communities (Reitz, 2007). 
Omidvar and Richmond (2003) reiterate that settlement is a continuous process but to the detriment of the newcomer, current funding is only focused on the initial stages of adaptation. As cited by the authors, after the primary phase, in the 'middle or intermediate' stage newly arrived immigrants require assistance with municipal services with their principal focus being access to the labour market, in addition to housing, health care, legal aid and occupation specific language training. In the 'long term' or 'final stage' immigrants seek to be fully incorporated in the economic, cultural, social and political life of Canada.

With regards to labour market access programs, Reitz (2007) points to the diffuse and unfocused nature of these policies as well as to their diverse approach that contribute to newcomers' lack of awareness of the very programs that could improve their outcomes. In this regard, I believe that more funding should be allocated to employment services that are beneficial to newly arrived immigrants that would provide them with meaningful job attainment and help them to improve their skills. More emphasis should be placed therefore on bridging programs and upgrade opportunities to help newcomers enter their chosen professions. Pertaining to this, the current financial assistance model at the federal and provincial levels that distributes funds to service providers who identify particular needs could be reviewed and a more practical approach adopted. More systematic evaluations of job acquisition programs should also be carried out. In conclusion, the governmental strategies of social inclusion for newcomers in identifying their deficiencies and aiming to make them more employable instead of tackling the systemic barriers that directly affect immigrant employment success could also be reviewed. 


\title{
APPENDIX A: CATEGORIES/SUB CATEGORIES USED IN THE DATA COLLECTION PROCESS (Review of the Literature)
}

\author{
Barriers to Access to Employment
}

\section{Credential Assessment}

- Canadian Licensing Organizations' reluctance to recognize foreign credentials

- Regulatory bodies actively engage in the exclusion of immigrants from the more skilled positions in the labour market

- Professional organizations and the state work in tandem to reserve the most desirable occupations for the native born population and those who were educated in Canada

\section{Racism/Discrimination (Employer's discriminatory hiring practices and initiatives)}

- Beliefs that foreign credentials are of an inferior quality even after being recognized by the appropriate licensing organization

- Use of 'Canadian Experience' as an exclusionary measure for newly arrived immigrants from the labour market (serves as an informal exclusionary measure for immigrant workers especially in unregulated professions)

- Prejudice and discrimination based on foreign origins

- Prejudice and discrimination based on racial or ethnic background

\section{Devaluation of Foreign Human Capital}

- Proficiency in either one of Canada's official languages

- Use of occupation specific terminology and communicating effectively in the workplace

- Newcomer's possession of an 'accent'

- $\quad$ Social Networking Ties

\section{Employers' Hiring Strategies}

- Internet based recruiting (Bulletin Board System (BBS) in conjunction with OCR scanners and web-based applications to streamline the job application process and sift out entire groups of applicants

- Internal hiring

- 'Canada First' mentality

- Telephone interviews 


\section{APPENDIX B: CONTENT TABLE}

(For the purposes of this research, a profile of the Immigrant Serving organizations is provided but organizations will remain anonymous)

\begin{tabular}{|c|c|c|c|}
\hline Organization & Program \& Description & Target Market & Data Summary \\
\hline $\begin{array}{l}\text { A) Non-profit } \\
\text { community based } \\
\text { organization }\end{array}$ & $\begin{array}{l}\text { Job Search Workshop } \\
\text { Transition to Employment } \\
\text { Program in conjunction with } \\
\text { an unpaid work placement or } \\
\text { mentorship. Aims to improve } \\
\text { labour market access } \\
\text { outcomes for newcomers. } \\
\text { Program components include: } \\
\text { needs assessment; individual } \\
\text { job search coaching; a two- } \\
\text { week workshop which } \\
\text { focuses on employer } \\
\text { perspectives, developing job } \\
\text { search skills, and effective } \\
\text { networking }\end{array}$ & $\begin{array}{l}\text { Permanent Residents } \\
\text { live-in caregivers, } \\
\text { convention refugees, } \\
\text { individuals who have } \\
\text { been granted permanent } \\
\text { resident status pending } \\
\text { completion of } \\
\text { background check, } \\
\text { individuals with } \\
\text { occupational goals, } \\
\text { individuals with high } \\
\text { English language } \\
\text { literacy skills (CLB5) }\end{array}$ & $\begin{array}{l}\text { Published material reveals that } \\
\text { information focuses on } \\
\text { understanding foreign experience } \\
\text { in Canadian terms and employer's } \\
\text { hiring strategies. Participants } \\
\text { obtain career specific knowledge } \\
\text { and information to develop skills } \\
\text { necessary for an effective job } \\
\text { search and learn how to format } \\
\text { resumes according to Canadian } \\
\text { criteria. After successful } \\
\text { completion of workshop, } \\
\text { participants would be eligible to } \\
\text { participate in an unpaid work } \\
\text { placement and mentorship } \\
\text { opportunity for four to twelve } \\
\text { weeks. }\end{array}$ \\
\hline $\begin{array}{l}\text { B) Not-for-profit-agency } \\
\text { that offers a wide range } \\
\text { of services to newcomers } \\
\text { including information and } \\
\text { referral, language } \\
\text { training, employment } \\
\text { preparation and } \\
\text { mentoring and settlement } \\
\text { services. }\end{array}$ & $\begin{array}{l}\text { Job Search Workshop is } \\
\text { designed to help individuals } \\
\text { access labour market } \\
\text { information and learn about } \\
\text { practices in their field. } \\
\text { Workshops consist of two } \\
\text { one-week modules that } \\
\text { prepare participants for the } \\
\text { Canadian labour market. }\end{array}$ & $\begin{array}{l}\text { Permanent Resident, } \\
\text { convention refugee, } \\
\text { live-in caregiver, } \\
\text { individuals with an } \\
\text { intermediate level of } \\
\text { English (CLB 5) }\end{array}$ & $\begin{array}{l}\text { Published material reveals that } \\
\text { participants of workshop are } \\
\text { equipped with strategies on how } \\
\text { to build social networking and } \\
\text { professional ties and attitudinal } \\
\text { changes such as how to improve } \\
\text { their self-confidence. Individuals } \\
\text { are also garnered with knowledge } \\
\text { on Canadian job search methods, } \\
\text { strategies and business } \\
\text { perspectives as well as how to } \\
\text { create a targeted resume and cover } \\
\text { letter. No information is provided } \\
\text { on credential assessment or } \\
\text { racism/discrimination as barriers } \\
\text { to employment. }\end{array}$ \\
\hline $\begin{array}{l}\text { C) Community based } \\
\text { organization that offers } \\
\text { services in employment, } \\
\text { health and wellness as } \\
\text { well as housing and } \\
\text { immigration and } \\
\text { settlement. }\end{array}$ & $\begin{array}{l}\text { i) Job Search Workshop } \\
\text { offers pre-employment } \\
\text { training to newcomers to } \\
\text { Canada and assists them to } \\
\text { better understand the different } \\
\text { steps in the job search } \\
\text { process, job search strategies } \\
\text { and hiring and recruitment } \\
\text { practices in Canada. }\end{array}$ & Newcomers to Canada & $\begin{array}{l}\text { Information garnered from } \\
\text { published material reveals that } \\
\text { participants are equipped with } \\
\text { knowledge on how and where to } \\
\text { network. Individuals also develop } \\
\text { resume creation skills according } \\
\text { to Canadian standards. No } \\
\text { information is provided on } \\
\text { credential assessment or } \\
\text { racism/discrimination as barriers } \\
\text { to employment. }\end{array}$ \\
\hline
\end{tabular}




\begin{tabular}{|c|c|c|c|}
\hline Organization & Program \& Description & Target Market & Data Summary \\
\hline & $\begin{array}{l}\text { ii) Employment Ontario } \\
\text { Program }\end{array}$ & $\begin{array}{l}\text { Individuals who are } \\
\text { looking for work }\end{array}$ & $\begin{array}{l}\text { Participants are equipped with } \\
\text { networking skills and partake in } \\
\text { employment focused workshops } \\
\text { based on resume and cover letter } \\
\text { writing and critiquing and } \\
\text { interview skills and practice. } \\
\text { They also research companies } \\
\text { and practise submitting job } \\
\text { applications to current postings } \\
\text { in the Arts, administration and } \\
\text { other areas of employment. }\end{array}$ \\
\hline $\begin{array}{l}\text { D) Multicultural, } \\
\text { multiservice organization } \\
\text { providing services in } \\
\text { settlement, language } \\
\text { instruction, employment } \\
\text { preparation and skills } \\
\text { training as well as } \\
\text { programs for children and } \\
\text { youth. }\end{array}$ & $\begin{array}{l}\text { Job Search Workshop is a pre- } \\
\text { employment program delivered } \\
\text { over four days. Participants } \\
\text { conduct labour market research } \\
\text { and develop initial career } \\
\text { plans. Successful completion of } \\
\text { program deems individuals } \\
\text { eligible for further employment } \\
\text { support and job development. }\end{array}$ & Newcomers to Canada & $\begin{array}{l}\text { Provides clients with information } \\
\text { on the Canadian labour market as } \\
\text { well as employment counseling. } \\
\text { Participants develop a blueprint } \\
\text { for initial career plans. No } \\
\text { information is provided on the } \\
\text { accreditation process, } \\
\text { racism/discrimination, and } \\
\text { employee's personal conditions. }\end{array}$ \\
\hline $\begin{array}{l}\text { E) Community-based } \\
\text { multicultural agency with } \\
\text { a focus on providing } \\
\text { services to new } \\
\text { Canadians and their } \\
\text { families. }\end{array}$ & $\begin{array}{l}\text { Job Search Workshop- } \\
\text { Employment Services for } \\
\text { newcomer professionals } \\
\text { seeking employment in their } \\
\text { field. Participants may be } \\
\text { eligible for mentoring and } \\
\text { work placement opportunities } \\
\text { pending successful completion } \\
\text { of workshop. }\end{array}$ & $\begin{array}{l}\text { Newcomers to Canada } \\
\text { (Individuals with } \\
\text { international } \\
\text { experience) } \\
\text { - Participants must be } \\
\text { able to communicate } \\
\text { in English and must } \\
\text { have occupational } \\
\text { training and } \\
\text { experience. Must be } \\
\text { eligible to work in } \\
\text { Canada. }\end{array}$ & $\begin{array}{l}\text { Participants are taught how to } \\
\text { network with confidence and } \\
\text { develop effective interviewing } \\
\text { techniques, in addition to resume } \\
\text { creation, cover letter writing and } \\
\text { interview follow up letters. } \\
\text { Individuals also learn about } \\
\text { employer hiring strategies. }\end{array}$ \\
\hline $\begin{array}{l}\text { F) Not-for-profit } \\
\text { charitable organization } \\
\text { that offers employment } \\
\text { programs and services to } \\
\text { help individuals find jobs } \\
\text { in their field. }\end{array}$ & $\begin{array}{l}\text { i) Job Search Workshop } \\
\text { Program aims to equip clients } \\
\text { with skills, strategies and } \\
\text { business perspectives and helps } \\
\text { them to create a blueprint for } \\
\text { the next steps of their job } \\
\text { search. } \\
\text { ii) Employment Ontario } \\
\text { Program provides resources } \\
\text { and information, employment } \\
\text { workshops, career counseling } \\
\text { and connection to employers. }\end{array}$ & All job seekers & $\begin{array}{l}\text { Participants are equipped with } \\
\text { effective networking skills and } \\
\text { garnered with knowledge on the } \\
\text { Canadian labour market and } \\
\text { business perspectives. They also } \\
\text { learn how to conduct a successful } \\
\text { job search and participate in } \\
\text { mock interviewing. } \\
\text { Published material reveals that } \\
\text { Employment Ontario program } \\
\text { provides minimal guidance on } \\
\text { professional licensing and } \\
\text { certification, credential } \\
\text { assessments, job trends and } \\
\text { labour market information. }\end{array}$ \\
\hline
\end{tabular}




\begin{tabular}{|c|c|c|c|}
\hline Organization & Program \& Description & Target Market & Data Summary \\
\hline & & & $\begin{array}{l}\text { Participants are also provided } \\
\text { with work placements to gain } \\
\text { Canadian experience and } \\
\text { mentorship opportunities to } \\
\text { obtain industry and occupation } \\
\text { specific information and help } \\
\text { them to build a network in } \\
\text { Canada. Clients are also } \\
\text { equipped with workplace } \\
\text { communication skills and } \\
\text { workshops include resume } \\
\text { development, interview practice } \\
\text { and self marketing techniques. }\end{array}$ \\
\hline $\begin{array}{l}\text { G) Non-profit } \\
\text { organization that provides } \\
\text { career exploration, job } \\
\text { search support, } \\
\text { employment recruitment } \\
\text { and social and assessment } \\
\text { services. }\end{array}$ & $\begin{array}{l}\text { i) Job Search Workshop } \\
\text { Program provides } \\
\text { internationally trained } \\
\text { professionals with the } \\
\text { necessary tools to integrate into } \\
\text { the Canadian labour market } \\
\text { and reach realistic employment } \\
\text { goals, so that they can become } \\
\text { self sufficient. } \\
\text { ii) Employment Ontario } \\
\text { Program }\end{array}$ & $\begin{array}{l}\text { Unemployed } \\
\text { newcomers to Canada } \\
\text { seeking support with } \\
\text { their transition to the } \\
\text { Canadian job market. } \\
\text { All individuals } \\
\text { looking for } \\
\text { employment including } \\
\text { the unemployed and } \\
\text { underemployed, } \\
\text { students, apprentices } \\
\text { and the internationally } \\
\text { trained. }\end{array}$ & $\begin{array}{l}\text { Combats the barrier of a lack of } \\
\text { 'Canadian experience' by } \\
\text { providing work placements for } \\
\text { program participants. Job search } \\
\text { assistance is provided through } \\
\text { pre-employment preparation } \\
\text { workshops and one-on-one } \\
\text { coaching. } \\
\text { Participants are provided with } \\
\text { job placements which offer } \\
\text { subsidies to employers and are } \\
\text { garnered with knowledge on } \\
\text { resume creation. They also } \\
\text { develop job interview skills and } \\
\text { practise cold calling to } \\
\text { employers. }\end{array}$ \\
\hline $\begin{array}{l}\text { H) Multi-cultural non- } \\
\text { profit community based } \\
\text { organization that provides } \\
\text { settlement, employment } \\
\text { and self-employment } \\
\text { services with priority to } \\
\text { immigrants, youth, } \\
\text { visible minority people } \\
\text { and low-income women. }\end{array}$ & $\begin{array}{l}\text { i) Job Search Workshop } \\
\text { Program focuses on developing } \\
\text { skills for job acquisition and } \\
\text { entails activities such as } \\
\text { researching employers, } \\
\text { creating an action plan and job } \\
\text { search strategies. } \\
\text { ii) Employment Ontario } \\
\text { Program helps Ontarians find } \\
\text { sustainable employment and } \\
\text { offers a range of resources and } \\
\text { support services to cater to the } \\
\text { career needs of clients. }\end{array}$ & $\begin{array}{l}\text { Job ready newcomers } \\
\text { who possess LINC } \\
\text { level } 4 \text { or higher } \\
\text { English language } \\
\text { skills. } \\
\text { Unemployed or } \\
\text { underemployed } \\
\text { individuals; those in } \\
\text { short term survival } \\
\text { jobs; people who are } \\
\text { out of school and } \\
\text { those legally entitled } \\
\text { to work in Canada. }\end{array}$ & $\begin{array}{l}\text { Published material reveal that job } \\
\text { search preparation workshops } \\
\text { focus on developing networking } \\
\text { and interview skills and writing a } \\
\text { targeted resume and cover letter. } \\
\text { Participants are garnered with } \\
\text { Canadian experience through job } \\
\text { training and trial opportunities } \\
\text { and provided with information } \\
\text { about the Canadian labour } \\
\text { market. They are also taught how } \\
\text { to match their skills and interests } \\
\text { with those of employer's. }\end{array}$ \\
\hline
\end{tabular}




\begin{tabular}{|c|c|c|c|}
\hline Organization & Program \& Description & Target Market & Data Summary \\
\hline $\begin{array}{l}\text { I) Community based not- } \\
\text { for profit agency with a } \\
\text { focus on employment. } \\
\text { Also provides settlement } \\
\text { information to } \\
\text { newcomers. }\end{array}$ & $\begin{array}{l}\text { Job Search Workshop Program } \\
\text { assists newcomers to Canada to } \\
\text { find employment that is } \\
\text { commensurate with their } \\
\text { qualifications. }\end{array}$ & Newcomers to Canada & $\begin{array}{l}\text { Pre-employment workshops } \\
\text { equip participants with effective } \\
\text { job search skills and knowledge } \\
\text { of Canadian employer } \\
\text { expectations. }\end{array}$ \\
\hline J) Ethno-specific agency & $\begin{array}{l}\text { Job Search Workshop helps } \\
\text { newcomers develop job search } \\
\text { skills, tools and understanding } \\
\text { of the Canadian labour market. } \\
\text { Workshops are approximately } 4 \\
\text { days in length and also educate } \\
\text { newcomers on workers' rights } \\
\text { and employment standards. }\end{array}$ & Immigrant women & $\begin{array}{l}\text { Workshops focus on building } \\
\text { effective networking skills and } \\
\text { resume and cover letter writing, } \\
\text { as well as developing successful } \\
\text { interview techniques. }\end{array}$ \\
\hline $\begin{array}{l}\text { K) Employment Centre } \\
\text { operated by educational } \\
\text { institution that provides } \\
\text { both job seekers and } \\
\text { employers, access to a } \\
\text { full range of employment } \\
\text { and recruitment services } \\
\text { and supports. }\end{array}$ & Employment Ontario Program & $\begin{array}{l}\text { Newcomers to } \\
\text { Canada, jobseekers, } \\
\text { employers }\end{array}$ & $\begin{array}{l}\text { Combats barrier of lack of } \\
\text { Canadian experience by offering } \\
\text { a job development, placement } \\
\text { and support service. Equips } \\
\text { participants with networking } \\
\text { skills. Published material reveals } \\
\text { that individuals are primarily } \\
\text { taught how to conduct an } \\
\text { effective job search, resume } \\
\text { writing and interview skills and } \\
\text { are garnered with labour market } \\
\text { information. }\end{array}$ \\
\hline $\begin{array}{l}\text { L) Employment Centre } \\
\text { operated by educational } \\
\text { institution. }\end{array}$ & Employment Ontario Program & $\begin{array}{l}\text { Internationally trained } \\
\text { participants with } \\
\text { experience in their } \\
\text { field, an intermediate } \\
\text { level of English or } \\
\text { higher and who work } \\
\text { less than twenty hours } \\
\text { per week; all job } \\
\text { seekers }\end{array}$ & $\begin{array}{l}\text { Offers unpaid volunteer work } \\
\text { placements. Workshops focus on } \\
\text { the job search process, resume } \\
\text { writing and interview skills, the } \\
\text { Canadian labour market and } \\
\text { contacting employers. }\end{array}$ \\
\hline
\end{tabular}




\begin{tabular}{|c|c|c|c|}
\hline Organization & Program \& Description & Target Market & Data Summary \\
\hline $\begin{array}{l}\text { M) Employment } \\
\text { Organization committed } \\
\text { to assisting individuals } \\
\text { with their job search } \\
\text { while providing them } \\
\text { with the right tools and } \\
\text { resources. }\end{array}$ & Employment Ontario Program & $\begin{array}{l}\text { All job seekers who } \\
\text { are eligible to work in } \\
\text { Canada }\end{array}$ & $\begin{array}{l}\text { Provides participants with } \\
\text { Canadian experience by } \\
\text { facilitating opportunities for } \\
\text { apprenticeships and learning new } \\
\text { skills. Clients are also taught } \\
\text { effective networking skills. } \\
\text { Employment workshops include } \\
\text { resume and cover letter writing } \\
\text { and interview preparation and } \\
\text { practice. }\end{array}$ \\
\hline $\begin{array}{l}\mathrm{N}) \text { Ethno-specific } \\
\text { organization that provides } \\
\text { social, cultural and } \\
\text { educational programs to } \\
\text { meet the needs of the } \\
\text { membership and } \\
\text { community, while } \\
\text { promoting heritage. }\end{array}$ & Employment Ontario Program & $\begin{array}{l}\text { All job seekers } \\
\text { eligible to work in } \\
\text { Canada with a focus } \\
\text { on ethno racial } \\
\text { community members. }\end{array}$ & $\begin{array}{l}\text { Participants gain Canadian } \\
\text { experience through job } \\
\text { placement services and } \\
\text { apprenticeship opportunities. } \\
\text { They are given assistance with } \\
\text { their resumes and are able to } \\
\text { attend job search workshops. } \\
\text { Clients are also granted the } \\
\text { opportunity to liaise directly with } \\
\text { employers through onsite job } \\
\text { fairs. }\end{array}$ \\
\hline $\begin{array}{l}\text { O) Charitable } \\
\text { organization focused on } \\
\text { community support and } \\
\text { development. }\end{array}$ & Employment Ontario Program & $\begin{array}{l}\text { All job seekers } \\
\text { including the } \\
\text { unemployed, } \\
\text { underemployed, } \\
\text { students, newcomers } \\
\text { to Canada and the } \\
\text { internationally } \\
\text { trained. }\end{array}$ & $\begin{array}{l}\text { Provides participants with } \\
\text { opportunities for on-the-job } \\
\text { training and experience support. } \\
\text { Individuals also learn about the } \\
\text { Canadian labour market and } \\
\text { employer hiring strategies as well } \\
\text { as networking techniques. } \\
\text { Workshop topics include resume } \\
\text { and cover letter writing, } \\
\text { interview skills and preparation } \\
\text { and job search strategies. }\end{array}$ \\
\hline $\begin{array}{l}\text { P) Non-profit } \\
\text { organization with a focus } \\
\text { on job search, placement } \\
\text { and human resource } \\
\text { solutions for employers. }\end{array}$ & Employment Ontario Program & & $\begin{array}{l}\text { Provides participants with } \\
\text { assistance on resume creation } \\
\text { and improvement as well as } \\
\text { interview preparation. }\end{array}$ \\
\hline
\end{tabular}




\section{APPENDIX C: DESCRIPTION OF EMPLOYMENT WORKSHOPS OFFERED BY SERVICE PROVIDER ORGANIZATIONS}

- Interview Preparation

- Cover Letter Writing

- Resume Creation

- Social Networking

- Social Media Networking

- Effective Job Search Skills and Canadian employer expectations

- Entrepreneurship Options

- Provides assistance to newcomers to find employment in their field of expertise and provides information about licensing, work placement and understanding the Canadian workplace culture

- The Hidden Job Market

- Staying Employed

- Employer expectations- Getting along with your supervisor

- Introduction to Apprenticeship Workshops

- Marketing Yourself Effectively

- Teamwork- Fitting in and getting along with your coworkers

- Understanding the employee relationship

- Your self-concept. How does your self-image affect your work experience?

(For further information please consult: City of Toronto Portal- Newcomer Services - http://www.211toronto.ca; Ministry of Citizenship, Immigration and International Trade http://www.citizenship.gov.on.ca/english/newcomers/agencies.shtml) 


\section{References}

Adamuti-Trache, M. (2013). Language Acquisition among Adult Immigrants in Canada: The Effect of Premigration Capital. Adult Education Quarterly, 63(2), 103-126.

Ahamad, B., Roberts, M., Sobkow, J., \& Boothby, D. (2003). An Index of the Employment Opportunities for New Immigrants Based on Skills Transferability and Occupational Barriers. Final Report. Labour Market Policy Directorate. Human Resources and Skills Development Canada.

Alboim, N., Finnie, R., \& Meng, R. (2005). The Discounting of Immigrants' Skills in Canada. Evidence and Policy Recommendations. IRPP Choices, 11(2), 1-28.

Ann, T., Crisp, B. R., Nevill, A., Lamaro, G., Graham, M., \& Barter-Godfrey, S. (2009). Theorising Social Exclusion. London; New York: Routledge Taylor and Francis Group.

Askonas, P., \& Stewart, A. (2000). Social Inclusion. New York: St. Martin’s Press.

Aydemir, A., \& Skuterud, M. (2005). Explaining the Deteriorating Entry Earnings of Canada's Immigration Cohorts: 1996 - 2000. Canadian Journal of Economics, 38(2), 641-671.

Bambrah, Gurmeet. (2005). Canadian 'Experiments' in Diversity: The Case of Immigrants in Diversity: The Case of Immigrants with Engineering backgrounds who Settle in Ontario. CERIS Working Paper Series, No. 41.

Banerjee, R., \& Robson, W. P. (2009). Faster, Younger, Richer? The Fond Hope and Sobering Reality of Immigration's Impact on Canada's Demographic and Economic Future. No. 291. Toronto, ON: C.D. Howe Institute.

Bauder, H. (2003). "Brain Abuse" or the Devaluation of Immigrant Labour in Canada. Antipode, 35(4), 699-717.

Basran, G.S., \& Zong, L. (1998). Devaluation of foreign credentials as perceived by visible minority professional immigrants. Canadian Ethnic Studies, 30(3), 6-25.

Birrell, B., \& McIsaac, E. (2006). 'Addressing Skills Diversity' in From Immigration to Integration: Local Solutions to a Global Challenge. Organization for Economic Cooperation and Development.

Black, D. (2014, February 7). Tories propose sweeping citizenship rule changes. Toronto Star, p. A6. 
Block, S., \& Galabuzi, G. (2011). Canada's Colour Coded Labour Market: The Gap for Racialized Workers. Ottawa. Canadian Center for Policy Alternatives: Wellesley Institute.

Bolles, R.N. (2004). What Colour is Your Parachute? Berkeley, California: Ten Speed Press.

Byrne, D.S. (2005). Social Exclusion, 2nd ed. Maidenhead, England; New York: Open University Press.

Canadian Architectural Certification Board (CACB) (2003a). Request for assessment of academic qualifications (for graduates of Canadian schools of architecture prior to CACB accreditation). Ottawa. Retrieved from http://cacb.ca/documents/a2_foreign.pdf

Canadian Architectural Certification Board (CACB) (2003b). Request for assessment of academic qualifications (for graduates of foreign schools of architecture - with exemption of the United States). Ottawa. Retrieved from http://cacb.ca/documents/a2_foreign.pdf

Chiswick, B.R., \& Miller, P. W. (2001). A Model of Destination-Language Acquisition: Application to Male Immigrants to Canada. Demography, 38(3), 391-409.

Citizenship and Immigration Canada. (2005). Evaluation of the Immigrant Settlement and Adaptation Program (ISAP). Retrieved September, 2014 from http://www.cic.gc.ca/english/resources/evaluation/isap/success.asp

(2007). Annual Report to Parliament on Immigration. Ottawa: Minister of Public Works and Government Services.

(2010). Evaluation of the Language Instruction for Newcomers to Canada (LINC) Program. Evaluation Division. Retrieved November 12, 2013 from http://www.cic.gc.ca/english/resources/evaluation/linc/2010/linc-eval.pdf (2011a). Backgrounder. Settlement Funding Allocations for 2010-2011. Retrieved July, 2015 from http://www.cic.gc.ca/english/department/media/speeches/2011/2011-02-17.asp

(2011b). The Settlement Program- Stipulations for funding. National call for proposals. Guide to applicants. Retrieved from http://www.cic.gc.ca/english/pdf/cfplcfpguide2-2011.pdf

(2012a). Strategic Outcomes and Program Alignment Architecture (in effect April 1, 2011). Retrieved September, 2014 from http://www.cic.gc.ca/english/department/paa/2012/activity-31.asp 
(2012b). Facts and Figures Immigration Overview. Retrieved from

http://www.cic.gc.ca/english/resources/statistics/menu-fact.asp

Express Entry Pool. Retrieved August, 2015 from

http://www.cic.gc.ca/english/pdf/pub/ee-core-deck-eng.pdf

Determine your Eligibility - Federal Skilled Workers. Retrieved August, 2015

from http://www.cic.gc.ca/english/immigrate/skilled/apply-who.asp

Educational Credential Assessment Stipulation- Skilled Workers. Retrieved from http://www.cic.gc.ca/english/immigrate/skilled/assessment.asp

Couton, P. (2013). The Impact of Communal Organizational density on the labour market integration of Immigrants in Canada. Journal of International Migration, 51(1), 92-114.

Crandall and Eshleman (2003). A Justification-Suppression Model of the Expression and Experience of Prejudice. Psychological Bulletin, 129 (3), 414-446.

Deters, P. (2011). Identity, Agency and the Acquisition of Professional Language and Culture. London: Continuum International Publishing Group.

Debus, A., George, B., \& Petkov, P. (2008). Help Wanted: Labour shortage troubles deepen for SMEs in 2007. Retrieved October 2014 from http://www.cfib-fcei.ca/cfibdocuments/rr3056.pdf

Evans, B.M., \& Shields, J. (2005). The Third Sector: Neo-Liberal Restructuring, Governance, and the Remaking of State-Civil Society Relationships. CERIS - The Ontario Metropolis Centre. Working Paper No. 18.

Ferrer, A., \& Riddell, W.C. (2008). Education, Credentials and Immigrant Earnings. Canadian Journal of Economics, 41(1), 186-216.

Ferrer, A., Picot, G., \& Riddell, W.C. (2014). New Directions in Immigration Policy: Canada's Evolving Approach to the Selection of Economic Immigrants. International Migration Review, 48 (3), 846-867.

Fleury, D. (2007). A Study of Poverty and Working Poverty among Recent Immigrants to Canada. Ottawa: Human Resources and Social Development Canada, July. Retrieved from

http://www.hrsdc.gc.ca/eng/publications_resources/research/categories/inclusion/2007/sp _680_05_07_e/page01.shtm 
Frenette, M., \& Morrisette, R. (2005). Will They Ever Converge? Earnings of Immigrant and Canadian-Born Workers over the Last Two Decades. International Migration Review, 39(1), 228-257.

Galabuzi, G. (2006). Canada's Economic Apartheid: The Social Exclusion of Racialized Groups in Canada's New Century. Toronto, ON: Canadian Scholar's Press.

Galabuzi, G., \& Teelucksingh, C. (2010). Social Cohesion, Social Exclusion and Social Capital. Region of Peel Human Services.

Grant, H., \& Sweetman, A. (2004). Introduction to Economic and Urban Issues in Canadian Immigration Policy. Canadian Journal of Urban Research, 13(1), 1-24.

Green, D.A. \& Worswick, C. (2002). Earnings of Immigrant Men in Canada: The Roles of Immigrant Labour Market Entry Effects and Returns to Foreign Experience, University of British Columbia, Department of Economics. Prepared for Citizenship and Immigration Canada.

Job Search Workshops- Your First Step to Employment. Retrieved from http:// www.jswontario.org

Job Search Workshop Evaluation Final Report, March, 2012. Centre for Community Based Research, Kitchener, ON.

Kazemipur, A., \& Halli, S. (2000). The New Poverty in Canada: Ethnic Groups and Ghetto Neighbourhoods. Toronto: Thompson Educational Publishing. (2001). Immigrants and 'New Poverty': The Case of Canada. International Migration Review, 35(4), 1129-1156.

Kenney, J. (2011). Speaking notes for the Honourable Jason Kenney, P.C., M.P. Minister of Citizenship, Immigration and Multiculturalism at the Standing Committee on Citizenship and Immigration. (February 17, 2011). Retrieved from www.cic.gc.ca/english/department/media/speeches/2011/2011-02-17.asp

Lim, A., Lo, L., Siemiatycki, M., \& Doucet, M. (2005). Newcomer Services in the Greater Toronto Area: An Exploration of the Range and Funding Services of Settlement Services. CERIS. Working Paper No. 35.

Lo, L., Wang, S., Anisef, P., Preston, V., \& Basu, R. (2010). Recent Immigrants Awareness of, Access to, Use of and Satisfaction with Settlement Services in York Region. CERIS. Working Paper No. 79. 
Liu, E. (2007). A Descriptive Study of Employer's Attitudes and Practices in Hiring Newcomer Job Seekers. CERIS. No. 31.

Mentoring Partnership. Program information retrieved from http://www.thementoringpartnership.com

Ministry of Training Colleges. Program information retrieved from http://www.tcu.gov.on.ca/eng/employmentontario

Ministry of Citizenship Immigration and International Trade. Program information retrieved from http://www.citizenship.gov.on.ca

Munro, M.J., \& Derwing, T.M. (1999). Foreign Accent, Comprehensibility and Intelligibility in the Speech of Second Language Learners. Language Learning, 49(1), 285-310.

Munro, M.J. (2003). A Primer on Accent Discrimination in the Canadian Context. TESL Canada, 20(2), 38-51.

Nakhaie, M.R., \& Kazemipur, A. (2013). Social Capital, Employment and Occupational Status of the New Immigrants in Canada. International Migration and Integration, 14(3), 419437.

Omidvar, R., \& Richmond, T. (2003). Immigrant Settlement and Social Inclusion in Canada. Toronto, ON: Laidlaw Foundation.

Ontario Council of Agencies Serving Immigrants (2012). Making Ontario Home- A study of settlement and integration services for immigrants and refugees. Toronto, ON.

Ontario: Office of the Fairness Commissioner. (2013). A Fair Way to Go: Access to Ontario's Regulated Professions and the Need to Embrace Newcomers in the Global Economy. Retrieved August, 2015 from http://www.fairnesscommissioner.ca/files_docs/content/pdf/en/A\%20Fair\%20Way\%20to \%20Go\%20Full\%20Report\%20ENG\%20Jan\%202013.pdf

Oreopoulos, P., Walker, H., and Omidvar, R. (2015, October 27). Why Matthew but not Samir? Disrupting the Hiring Bias. Webinar for Employers. Hire Immigrants and Upwardly Global. Retrieved from http://www.hireimmigrants.ca

Oreopoulos, P., (2009). Why Do Skilled Immigrants Struggle in the Labour Market? A Field Experiment with Six Thousand Resumes. Vancouver, BC: Metropolis British Columbia.

Oreopoulos, P., \& Dechief, D.Y. (2011). Why do some employers prefer to interview Matthew but not Samir? New evidence from Toronto, Montreal and Vancouver. Vancouver, BC: Metropolis British Columbia. 
Owen, T. (2007). International Credential Evaluation and the Labour Market Integration of Immigrants. Canadian Issues, Spring. 39 - 42.

Pendakur, K., \& Pendakur, R. (1998). The colour of money: earnings differentials among ethnic groups in Canada. Canadian Journal of Economics, 31(3), 518-548.

Picot, G., \& Hou, F. (2003). The rise in low-income rates among immigrants in Canada. Ottawa: Statistics Canada, Analytical Studies Branch.

Picot, G. (2004). The Deteriorating Economic Welfare of Canadian Immigrants. Canadian Urban Research, 13(1), 25-45.

Picot, G., Hou, F., \& Coulombe, S. (2008). Chronic Low Income and Low-Income Dynamics among Recent Immigrants. Ottawa: Statistics Canada, Analytical Studies Branch.

Picot, G., \& Sweetman, A. (2005). The Deteriorating Economic Welfare of Immigrants and Possible Causes: Update 2005. Ottawa: Statistics Canada.

Picot, G., \& Sweetman, A. (2012). Making It in Canada: Immigration Outcomes and Policies. Montreal: Institute for Research on Pubic Policy. Study No. 29.

Reitz, J.G. (2001a). Immigrant Skill Utilization in the Canadian Labour Market: Implications of Human Capital Research. International Migration and Integration, 2(3), 347-378

(2001b). Immigrant Success in the Knowledge Economy: Institutional Change and the Immigrant Experience in Canada, 1970-1995. Social Issues, 57(3), 579-613.

Reitz, J.G. (2007). Immigrant Employment Success in Canada, Part 1: Individual and Contextual Causes. International Migration and Integration, 8(1), 11-36.

Reitz, J.G. (2014). Immigrant Skill Utilization: Trends and Policy Issues. International Migration and Integration, 15(1), 1-26.

Reitz, J.G., \& Sklar, S. (1997). Culture, Race and the Economic Assimilation of Immigrants. Sociological Forum, 12(2), 233-277.

Reitz, J.G., \& Banerjee, R. (2007). Racial Inequality, Social Cohesion and Policy Issues in Canada. In T.J. Courchene, K. Banting and W. Wuttunee (eds.) Belonging, Diversity, Recognition and Shared Citizenship in Canada. Montreal: Institute for Research on Public Policy. 
Reitz, J.G., Breton, R., Dion, K.K., Dion, K.L., Phan, M.B., \& Banerjee, R. (2009). Multiculturalism and Social Cohesion: Potentials, and Challenges of Diversity. New York: Springer.

Richmond, T., \& Shields, J. (2004). Third Sector Restructuring and the New Contracting Regime: The Case of Immigrant Serving Agencies in Ontario. CERIS, Policy Matters, No. 3.

RBC Financial Group. (2005). "The Diversity Advantage: A Case for Canada's 21 ${ }^{\text {st }}$ Century Economy". Retrieved from http://www.rbc.com/newsroom/pdf/20051020diversity.pdf

Sadiq, K. (2004). The Two-Tier Settlement System: A Review of Current Newcomer Settlement Services in Canada. CERIS. Working Paper No. 34.

Saks, A. (1994). A Reconceptualization of the theory behind recruitment source effectiveness. Proceedings of the Annual Conference of the ASAC, HR Division, Halifax, NS.

Schellenberg, G., \& Hou, F. (2005). The Economic Well-Being of Recent Immigrants to Canada. Canadian Issues, Spring, 49-52. Statistics Canada

Statistics Canada (2007). Immigrants' perspectives on their first four years in Canada: Highlights from three waves of the Longitudinal Survey of Immigrants to Canada. Ottawa: Minister of Industry.

Seidle, L.F. (2010). The Canada-Ontario Immigration Agreement: Assessment and Options for Renewal. Mowat Centre for Policy Innovation. Retrieved from http://www.mowatcentre.ca/research-topic-mowat.php?mowatResearchID=12

Shields, J. (2003). No Safe Haven: Markets, Welfare and Migrants. CERIS, Working Paper No. 22.

Shields, J., Kelly, P., Park, S., Prier, N., \& Fang, T. (2011 a). Profiling Immigrant Poverty in Canada: A 2006 Census Statistical Portrait. Canadian Review of Social Policy, 65/66, 92111.

Shields, J., Murnaghan, A., Lemoine, M., Kelly, P., \& Park, S. (2011b). How do immigrants find jobs? Toronto Immigrant Employment Data Initiative. Analytical Report 17.

Skills International. Program information retrieved from http:// www.skillsinternational.ca 
Smith, A. (2010). CICs Modernized Approach to Settlement Programming: A Brief Description. Retrieved from http://integration-net.ca:81/infocentre/2010/001e.pdf

Statistics Canada (2009). Quality of employment in the Canadian immigrant labour market. The Daily, November 23. Retrieved from http://www.statcan.gc.ca/dailyquotidien/091123/dq091123b-eng.htm

Teelucksingh, C., \& Galabuzi, G. (2005). Working Precariously: The impact of race and immigrants status on employment opportunities and outcomes in Canada. Toronto, ON: Canadian Race Relations Foundation.

Toronto Region Immigrant Employment Council. Program information retrieved from http://www.triec.ca

Tyrrell, M.W. The Electronic Hiring Hall: Changes in Job/Candidate Search Practices in The Early Silicon Age. Carleton University, pp. 1-21. Retrieved from http://www.carleton.ca/ mwtyrrel/papers/ehh.pdf

Wang, S., \& Truelove, M. (2003). Evaluation of Settlement Service Programs for Newcomers in Ontario: A Geographical Perspective. International Migration and Integration, 4(4), 577 607.

Walker, E.A \& Walker, C. (1997). Britain Divided: The Growth of Social Exclusion in the 1980s and 1990s. London: Child Poverty Action Group. 